\title{
Chemical and isotopic interpretation of major ion compositions from precipitation: a one-year temporal monitoring study in Wroclaw, SW Poland
}

\author{
M. Ciężka ${ }^{1}$ - M. Modelska ${ }^{2}$ - M. Górka ${ }^{1}$. \\ A. Trojanowska-Olichwer ${ }^{1} \cdot$ D. Widory $^{3}$
}

Received: 20 August 2014 / Accepted: 17 July 2015 /

Published online: 4 August 2015

(C) The Author(s) 2015. This article is published with open access at Springerlink.com

\begin{abstract}
The chemical compositions $\left(\mathrm{Na}^{+}, \mathrm{NH}_{4}^{+}, \mathrm{K}^{+}, \mathrm{Mg}^{2+}, \mathrm{Ca}^{2+}, \mathrm{Cl}^{-}, \mathrm{NO}_{2}{ }^{-}, \mathrm{NO}_{3}{ }^{-}, \mathrm{SO}_{4}{ }^{2-}\right.$, $\mathrm{HCO}_{3}{ }^{-}$) of wet precipitation and nitrogen isotope compositions $\delta^{15} \mathrm{~N}\left(\mathrm{NH}_{4}{ }^{+}\right)$were studied from January to December 2010 in Wrocław (SW Poland). Results of a principle component analysis show that $82 \%$ of the data variability can be explained by three main factors: 1) F1 (40\%) observed during vegetative season (electrical conductivity, $\mathrm{HCO}_{3}{ }^{-}, \mathrm{NO}_{3}{ }^{-}, \mathrm{NO}_{2}{ }^{-}$, $\mathrm{NH}_{4}{ }^{+}$and $\mathrm{SO}_{4}{ }^{2-}$ ), mainly controlling rainwater mineralization; 2) F2 (26\%) observed during vegetative and heating seasons $\left(\mathrm{K}^{+}, \mathrm{Ca}^{2+}\right.$ and $\left.\mathrm{Mg}^{2+}\right)$, probably representing a combination of two processes: anthropogenic dusts and fertilizers application in agricultural fields, and 3) F3 $(16 \%)$ reported mainly during heating season $\left(\mathrm{Na}^{+}\right.$and $\left.\mathrm{Cl}^{-}\right)$probably indicating the influence of marine aerosols. Variations of $\left.\delta^{15} \mathrm{~N} \mathrm{NH}_{4}{ }^{+}\right)$from -11.5 to $18.5 \%$ identify three main pathways for the formation of $\mathrm{NH}_{4}^{+}:$1) equilibrium fractionation between $\mathrm{NH}_{3}$ and $\mathrm{NH}_{4}^{+}$; 2) kinetic exchange between $\mathrm{NH}_{3}$ and $\mathrm{NH}_{4}^{+}$; 3) $\mathrm{NH}_{4}{ }^{+}$exchange between atmospheric salts particles and precipitation. The coupled chemical/statistical analysis and $\delta^{15} \mathrm{~N}\left(\mathrm{NH}_{4}^{+}\right)$approach shows that while fossil fuels burning is the main source of $\mathrm{NH}_{4}{ }^{+}$in precipitation during the heating season, during the vegetative season $\mathrm{NH}_{4}{ }^{+}$originates from local sewage irrigation fields in Osobowice or agricultural fertilizers.
\end{abstract}

Electronic supplementary material The online version of this article (doi:10.1007/s10874-015-9316-2) contains supplementary material, which is available to authorized users.

\section{Ciężka}

monika.ciezka@ing.uni.wroc.pl

1 Department of Applied Geology, Geochemistry and Environmental Management, Institute of Geological Sciences, University of Wrocław, Cybulskiego 32, 50-205 Wrocław, Poland

2 Department of General Hydrogeology, Institute of Geological Sciences, University of Wroclaw, Cybulskiego 32, 50-205 Wrocław, Poland

3 GEOTOP/UQAM, Earth and Atmospheric Sciences Department, Case postale 8888 Succursale Centre-Ville, Montréal, QC H3C 3P8, Canada 
Keywords Precipitation -Ammonium - Chemical composition PCA P Stable nitrogen isotopes · Urban area

\section{Introduction}

Precipitation is one of the best scavengers for removing particulate matter and gaseous pollutants from the atmosphere. The efficiency of this process reflects in their chemical compositions and pH values (Migliavacca et al. 2005; Prathibha et al. 2009). Chemical composition of precipitation is an important issue for many regions worldwide (e.g. Asia, eastern North America, Europe) as it can lead to eutrophication, affect ecosystems or contribute to global climate change (Calvo et al. 2010). Many studies focused on the chemical composition of rainwater from a spatio-temporal point of view (Avila 1996; Puxbaum et al. 1998; Galy-Lacaux and Modi 1998; Al-Momani et al. 2000; Topçu et al. 2002; Safai et al. 2004; Tu et al. 2005; Yoboue et al. 2005; Zhang et al. 2012) and identified several factors that can affect the chemical composition of rainwater: local pollutants, meteorological conditions, location, processes responsible for transport of pollutants (Rocha et al. 2003; Zhao et al. 2008). Chemical composition of precipitation can also provide information about both the main sources of pollutants and their migration processes (Ayres et al. 1995; Zunckel et al. 2003). A difference between ion constituents in rainwater on natural and anthropogenic sites exists. In coastal areas precipitation is mainly dominated by marine aerosols with high concentrations of $\mathrm{Na}^{+}$and $\mathrm{Cl}^{-}$(Parungo et al. 1990; Ceron et al. 2002), whereas nitrogen (N) and sulphur (S) compounds dominate rural, urban and agricultural areas and reflect anthropogenic influence, such as fossil fuels combustion, fertilizers application on fields or specific sewage treatments (Das et al. 2005; Górka et al. 2014). The chemical composition of precipitation was also determined in Poland (Jóźwiak and Kozłowski 2005; Kacorzyk et al. 2012) including Wrocław and its vicinity (Kmieć et al. 1994; Czyżyk and Rajmund 2011). Chemical composition of precipitation and bulk precipitation in Wroclaw is monitored by the Voivodeship Inspectorate for Environmental Protection (VIfEP) that publishes results in yearly reports (e.g. VIfEP Report 2010).

Isotope approaches as complementary tools to chemical composition of precipitation have already proven their added value to identify the origin of pollutants (e.g. Caron and Tessier 1986; Lee et al. 2012; Xiao et al. 2012; Lim et al. 2014). Similar approaches have already been used for characterising precipitation in Wroclaw (SW Poland) (Górka et al. 2008; Szynkiewicz et al. 2008; Górka et al. 2011). Isotopes analysis of inorganic N, an important pollutant, have also been presented by other authors (e.g. Hoering 1957; Moore 1977; Freyer 1978a, b; Heaton 1987; Xiao et al. 2012; Felix et al. 2013) however not for Poland yet to our knowledge. Atmospheric $\mathrm{NH}_{3}$ is emitted from soils, oceans and is excreted by animals (Xiao and Liu 2002); anthropogenic sources include domestic animal excreta, fertilizers and biomass burning (Prospero et al. 1986; Hegg et al. 1988; Denterer and Crutzen 1994; Russell et al. 1998; Xiao and Liu 2002; Battye et al. 2003; Sapek 2013; Prenni et al. 2014). Nitrogen isotope composition of ammonium $\left(\delta^{15} \mathrm{~N}\left(\mathrm{NH}_{4}{ }^{+}\right)\right)$shows wide variations from $\delta^{15} \mathrm{~N}$ highly depleted in ${ }^{15} \mathrm{~N}(\sim-18.0 \%)$ to highly enriched in ${ }^{15} \mathrm{~N}\left(\sim 10.0 \%\right.$ ), depending on the origin of $\mathrm{NH}_{4}{ }^{+}$(Moore 1977; Freyer $1978 \mathrm{a}, \mathrm{b}$; Heaton 1987). We are studying here, for the first time in Poland, the $\delta^{15} \mathrm{~N}\left(\mathrm{NH}_{4}{ }^{+}\right)$in order to trace the origin of nitrogen compounds in precipitation. Principal Component Analysis (PCA) can also provide additional information about processes and 
sources affecting the overall composition of precipitation (Plaisance et al. 1996; Cao et al. 2009; Calvo et al. 2010). The aim of this study is thus to characterise the processes involved in the genesis of major ions in precipitation in Wroclaw. We are also investigating seasonal variability based on relationships between chemical and isotope characteristics. This study uses a novel approach for characterising precipitation using an approach coupling chemical, isotope and statistical data from a 1-year (2010) monitoring in Wrocław.

\section{Materials and methods}

\subsection{Study area}

Wrockaw is the largest city $(630,000$ inhabitants) in the Lower Silesia region in southwestern Poland, at the feet of the Sudety Mountains. Surface area of the city is $293 \mathrm{~km}^{2}$, and consists of: agricultural lands $\left(132 \mathrm{~km}^{2}\right)$, forests and woodlands $\left(16.5 \mathrm{~km}^{2}\right)$, water $\left(9.6 \mathrm{~km}^{2}\right)$, wasteland $\left(3.9 \mathrm{~km}^{2}\right)$, roads $\left(28.48 \mathrm{~km}^{2}\right)$, habitations $\left(85.08 \mathrm{~km}^{2}\right)$, the irrigation fields of Osobowice $\left(11 \mathrm{~km}^{2}\right)$ and others $\left(17.44 \mathrm{~km}^{2}\right)$. On its western part Wrocław is surrounded by agricultural lands. 5 large rivers flow through the city: the Odra River and its 4 tributaries (Oława, Widawa, Bystrzyca, Ślęza). 3 trans-national roads run through Wrocław. There are also two large railway stations, two inland navigation ports and one international airport. Wrocław is influenced by a temperate climate characterized by both continental and marine contexts. Wind directions are mainly western $(27.6 \%$ days $)$ and southern $(23.1 \%)$ with an average speed around $2.5 \mathrm{~m} \cdot \mathrm{s}^{-1}$. The mean annual temperature is $9.6{ }^{\circ} \mathrm{C}$ and the yearly rainfall average is $589 \mathrm{~mm}$ (Dubicki et al. 2002).

\subsection{Samples collection}

Rain samples were collected using a rain collector located in downtown Wrocław (Poland) (Fig. 1).

Forty-one precipitation samples (wet deposition) were collected at a $2 \mathrm{~m}$ height from January 2010 to December 2010 via a funnel (diameter of $0.8 \mathrm{~m}$ ) into $5 \mathrm{~L}$ plastic containers covered by plastic a grid to prevent contamination. The funnel was placed in an open space to avoid any canopy effect.

\subsection{Chemical analysis}

Each sample was filtered through a $1.2 \mu \mathrm{m} \mathrm{GF/C} \mathrm{filter} \mathrm{to} \mathrm{remove} \mathrm{organic} \mathrm{pollution.} \mathrm{Electrical}$ conductivity (EC) was measured using a Multi 340i WTW multiparameter gauge with a TetraCon $325 / \mathrm{S}$ electrode (precision of $\pm 1 \%$ ). $\mathrm{pH}$ of rainfall was calculated from the equation: $\mathrm{pH}=6.37+\log$ Alk (meq.L $\mathrm{L}^{-1}$ ) (Gomółka 1998). For alkalinity samples were titrated with $0.1 \mathrm{M}$ $\mathrm{HCl}$ (methyl orange used as a $\mathrm{pH}$ indicator) using automatic pipette (OP200 HTL; precision of $20 \mu \mathrm{L})$ for estimating the presence of carbonic acid. Cations $\left(\mathrm{Na}^{+}, \mathrm{NH}_{4}^{+}, \mathrm{K}^{+}, \mathrm{Mg}^{2+}, \mathrm{Ca}^{2+}\right)$ and anions $\left(\mathrm{Cl}^{-}, \mathrm{NO}_{2}{ }^{-}, \mathrm{NO}_{3}{ }^{-}, \mathrm{SO}_{4}{ }^{2-}\right)$ were measured using Alliance Waters High-Performance Liquid Chromatograph (HPLC) 2695 with a 432 Conductivity Detector and a 2998 Photodiode Array Detector, an IC-Pak Anion HR column (glauconate/borate eluent) and IC-Pak Cation $\mathrm{M} / \mathrm{D}$ column (EDTA/ $\mathrm{HNO}_{3}$ eluent). Before measurements each sample was filtered 


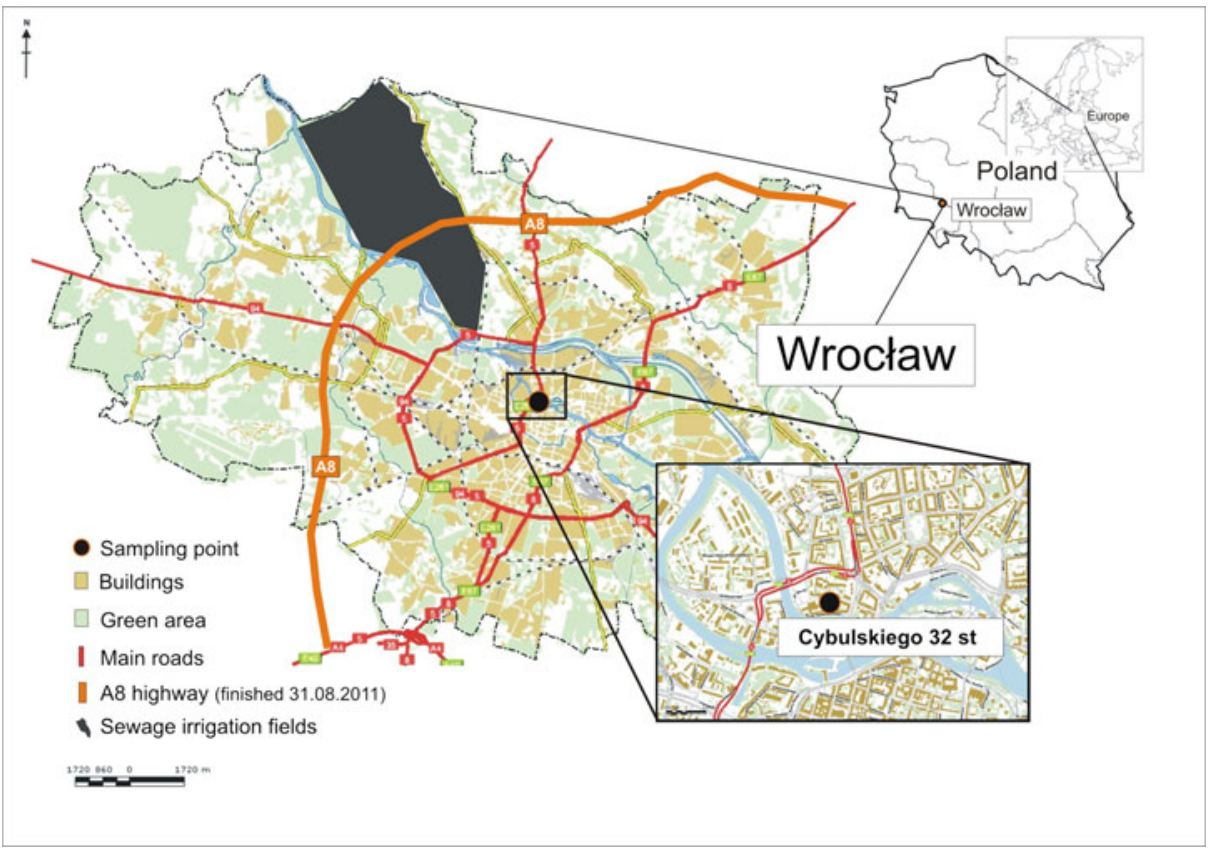

Fig. 1 Location of sampling area (Wroclaw, SW Poland)

through a $0.2 \mu \mathrm{m}$ syringe filter. The analytical precision of measurement for these ions was $0.01 \mathrm{mg} \cdot \mathrm{L}^{-1}$. Using a $100-\mu \mathrm{L}$ injection, the estimated method's detection limits (MDLs) were, in ppb: $\mathrm{Cl}^{-}(50), \mathrm{NO}_{2}^{-}(50), \mathrm{NO}_{3}^{-}$(75), $\mathrm{SO}_{4}^{2-}$ (75), $\mathrm{K}^{+}(15), \mathrm{Na}^{+}$(5). $\mathrm{Mg}^{2+}$ (10), $\mathrm{NH}_{4}^{+}(5)$, $\mathrm{Ca}^{2+}(15)$.

Ion were preconcentrated using ion exchange resins. Before gravity dripping through resins, samples were filtered through the GF/C filter and then placed in a $1 \mathrm{~L}$ glass separatory funnel. Bio-Rad AG 50W-X8 (hydrogen form) resin was used for the analysis due to its relatively high affinity for $\mathrm{NH}_{4}{ }^{+}$(Silva et al. 2000). Prior to dripping ions from the resin, the reagents as well as quartz wool and quartz tubes were prepared according to following steps:

1. $\mathrm{CuO}$ and $\mathrm{Cu}$ were calcinated at $400{ }^{\circ} \mathrm{C}$ for about $4 \mathrm{~h}$ in a muffle furnace to clean the reagents.

2. The $\mathrm{CaO}$ fraction of $1-2 \mathrm{~mm}$ was prepared following the procedures described in Boyd et al. (1994) and Kendall and Grim (1990).

3. Quartz tube $(20 \mathrm{~cm}$ length and $9 \mathrm{~mm}$ diameter $)$ and quartz wool were calcinated at $900{ }^{\circ} \mathrm{C}$ for about $1 \mathrm{~h}$.

\subsection{Procedure for eluting $\mathrm{NH}_{4}{ }^{+}$ions from the cation exchange resin column and analysing its $\delta^{15} \mathrm{~N}$}

Following the procedure described in Lehmann et al. (2001), the cation exchange resin loaded with $\mathrm{NH}_{4}^{+}$was dried in a muffle furnace at $50{ }^{\circ} \mathrm{C}$ and homogenized using an agate mortar. It 
was then loaded in a cleaned quartz tube with combustion reagents in the following order: (i) ground resin containing the $\mathrm{NH}_{4}{ }^{+}$ions, (ii) $100 \mathrm{mg}$ of copper oxide (CuO), (iii) $200 \mathrm{mg}$ of copper $(\mathrm{Cu}$ ), (iv) $500 \mathrm{mg}$ of calcium oxide (CaO), $100 \mathrm{mg}$ of $\mathrm{CuO}$, (v) $200 \mathrm{mg}$ of $\mathrm{Cu}$ and (vi) $500 \mathrm{mg}$ of $\mathrm{CaO}$. The tube was pumped down to $10^{-3} \mathrm{mbar}$ and sealed hermetically and burnt for $10 \mathrm{~h}$ in a muffle furnace following the modified procedure of Kendall and Grim (1990): (i) raising the temperature up to $900{ }^{\circ} \mathrm{C}$ within $1 \mathrm{~h}$ (ii) maintaining the temperature at $900{ }^{\circ} \mathrm{C}$ for $4 \mathrm{~h}$, (iii) cooling down to $600{ }^{\circ} \mathrm{C}$ for $3 \mathrm{~h}$ and (iv) maintaining for $2 \mathrm{~h}$ at $600{ }^{\circ} \mathrm{C}$ and finally cooling down to room temperature. At $900{ }^{\circ} \mathrm{C}$, organic pollutants are burnt and $\mathrm{AgNO}_{3}$ reacts with oxygen liberated by the $\mathrm{CuO}$. At $600{ }^{\circ} \mathrm{C}$ the carbon dioxide generated by the combustion of organic pollutants reacts with $\mathrm{CaO}$ to form calcium carbonate. At room temperature, created water is adsorbed onto the $\mathrm{CaO}$ particles to form $\mathrm{Ca}(\mathrm{OH})_{2}$. During the cooling steps nitrogen oxides are also reduced to $\mathrm{N}_{2}$ by $\mathrm{Cu}$, which does not require additional cryogenic purification and is ultimately used to measure the isotope ratio ${ }^{15} \mathrm{~N} /{ }^{14} \mathrm{~N}$ (Kendall and Grim 1990).

Analysis of the $\mathrm{N}$ isotope composition was carried out on a dual inlet Delta V Advantage mass spectrometer in the Laboratory of Isotope Geology and Geoecology at the Institute of Geological Sciences, University of Wrocław. International standards IAEA N-1 and N-2 were used to calibrate the data. $\delta^{15} \mathrm{~N}$ are reported relative to atmospheric nitrogen $\left(\mathrm{N}_{2}\right.$-Air). The error of the $\delta^{15} \mathrm{~N}$ determination is below $0.5 \%$.

\subsection{Statistical analysis}

Principal Component Analysis (PCA) is a very proven statistical method to characterise the spatio-temporal variability of large data population (e.g. Zhang et al. 1992; Manly 1998, Eder et al. 2014). PCA allows to abstract factors describing the variability of analysed population by using correlation matrixes and were used here with the intent to: (i) analyse the variability of several precipitation events simultaneously, (ii) discriminate sources of ions in precipitation, (iii) determine the respective contributions of those sources. PCA was carried out for 11 parameters: electrical conductivity (EC), $\mathrm{HCO}_{3}{ }^{-}, \mathrm{Cl}^{-}, \mathrm{NO}_{2}{ }^{-}, \mathrm{NO}_{3}{ }^{-}, \mathrm{SO}_{4}{ }^{2-}, \mathrm{Na}^{+}, \mathrm{NH}_{4}{ }^{+}, \mathrm{K}^{+}$, $\mathrm{Mg}^{2+}$ and $\mathrm{Ca}^{2+}$. PCA followed several steps: (i) elimination, (ii) testing of the distribution normality, (iii) choosing parameters for analysis, (iv) standardisation, (v) parameters transformation using the PCA method, (vi) "varimax" rotation, (vii) factor's loading and factor's scores extraction and interpretation of its variability (Johnson 1978; Manly 1998).

\section{Results}

\subsection{Weather conditions}

Air temperature varied from $-11^{\circ} \mathrm{C}$ (December 4,2010$)$ to $26^{\circ} \mathrm{C}$ (July 13, 2010) with an average value of $10.6{ }^{\circ} \mathrm{C}$ (median: $10^{\circ} \mathrm{C}$ ) (Table 1; Supplementary Materials). The average annual temperature $\left(8.4{ }^{\circ} \mathrm{C}\right)$ for 2010 was about $1.2{ }^{\circ} \mathrm{C}$ lower than the 9-year average measured between 2000 and 2009 (Dubicki et al. 2002). We divided the calendar year into three distinct periods according to the meteorological data: vegetative season and 2 heating seasons. Vegetative season is defined as the period where the daily average temperature is higher than $5{ }^{\circ} \mathrm{C}$. For 2010 we thus adopted the following periods: heating season I (January 14 to April 04), vegetative season (April 9 to October 16) and heating season II (October 13 to December 25). 
The sum of yearly precipitation (751 mm) (Meteorological Bulletin 2010) was significantly higher than average value observed from 2000 to 2009 (589 mm) (Dubicki et al. 2002).

The calculated $\mathrm{pH}$ in precipitation ranged from 4.5 (December 25, 2010) to 5.8 (May 3, 2010), with a mean value of 5.2 (median: 5.2) (Table 1; Supplementary Materials) and correspond to the ranges determined by VIEP in Wroclaw (VIfEP Report 2010). EC in precipitation varied from 12 (December 25, 2010) to $162 \mu \mathrm{S} \cdot \mathrm{cm}^{-1}$ (March 13, 2010), with a mean value of $71 \mu \mathrm{S} . \mathrm{cm}^{-1}$ (median: $61 \mu \mathrm{S} . \mathrm{cm}^{-1}$ ) (Table 1; Supplementary Materials).

\subsection{Chemical composition of precipitation}

$\mathrm{NO}_{2}{ }^{-}$concentrations varied from $<0.01 \mathrm{mg} \cdot \mathrm{L}^{-1}$ (May 21, 31, November 14, and December $12,25,2010$ ) to $2.9 \mathrm{mg} \cdot \mathrm{L}^{-1}$ (April 26, 2010) with an average value $0.9 \mathrm{mg} \cdot \mathrm{L}^{-1}$ (median: $0.7 \mathrm{mg} \cdot \mathrm{L}^{-1}$ ), $\mathrm{NO}_{3}{ }^{-}$ranged from $<0.01 \mathrm{mg} \cdot \mathrm{L}^{-1}$ (May 21 and November 14,2010 ) to $16.5 \mathrm{mg} \cdot$ $\mathrm{L}^{-1}$ (April 26, 2010) with an average value of $4.6 \mathrm{mg} \cdot \mathrm{L}^{-1}$ (median: $3.71 \mathrm{mg} \cdot \mathrm{L}^{-1}$ ), whereas $\mathrm{NH}_{4}{ }^{+}$concentrations ranged from $<0.01 \mathrm{mg} \cdot \mathrm{L}^{-1}$ (May 19, 21 and December 4, 2010) to $7.9 \mathrm{mg} \cdot \mathrm{L}^{-1}$ (April 26, 2010) with an average value of $2.8 \mathrm{mg} \cdot \mathrm{L}^{-1}$ (median: $2.1 \mathrm{mg} \cdot \mathrm{L}^{-1}$ ) (Table 1).

$\mathrm{Ca}^{2+}$ varied from $0.1 \mathrm{mg} \cdot \mathrm{L}^{-1}$ (December 25,2010 ) to $6.9 \mathrm{mg} \cdot \mathrm{L}^{-1}$ (July 13, 2010) with a mean value of $2.2 \mathrm{mg} \cdot \mathrm{L}^{-1}$ (median: $1.5 \mathrm{mg} \cdot \mathrm{L}^{-1}$ ), $\mathrm{Mg}^{2+}$ from $0.05 \mathrm{mg} \cdot \mathrm{L}^{-1}$ (December 25 , 2010 ) to $1.0 \mathrm{mg} \cdot \mathrm{L}^{-1}$ (December 5,2010 ) with a mean value of $0.3 \mathrm{mg} \cdot \mathrm{L}^{-1}$ (median: $0.2 \mathrm{mg}$. $\mathrm{L}^{-1}$ ), $\mathrm{K}^{+}$from $<0.01 \mathrm{mg} \cdot \mathrm{L}^{-1}$ (December $5,25,2010$ ) to $23.0 \mathrm{mg} \cdot \mathrm{L}^{-1}$ (November 14,2010 ) with a mean value $2.9 \mathrm{mg} \cdot \mathrm{L}^{-1}$ (median: $1.6 \mathrm{mg} \cdot \mathrm{L}^{-1}$ ), $\mathrm{Na}^{+}$from $<0.01 \mathrm{mg} \cdot \mathrm{L}^{-1}$ (April 5, August 31 , October 13,2010 ) to $12.9 \mathrm{mg} \cdot \mathrm{L}^{-1}$ (December 5,2010 ) with a mean value of $2.4 \mathrm{mg} \cdot \mathrm{L}^{-1}$ (median: $1.7 \mathrm{mg} \cdot \mathrm{L}^{-1}$ ), $\mathrm{SO}_{4}{ }^{2-}$ from $<0.01 \mathrm{mg} \cdot \mathrm{L}^{-1}$ (April 11, November 22, December 25,2010 ) to $24.5 \mathrm{mg} \cdot \mathrm{L}^{-1}$ (November 10,2010 ) with a mean value of $8.1 \mathrm{mg}$. $\mathrm{L}^{-1}$ (median: $5.6 \mathrm{mg} \cdot \mathrm{L}^{-1}$ ), $\mathrm{Cl}^{-}$from $0.7 \mathrm{mg} \cdot \mathrm{L}^{-1}$ (May 19,2010 ) to $18.6 \mathrm{mg} \cdot \mathrm{L}^{-1}$ (November

Table 1 Descriptive statistics for the main parameters

\begin{tabular}{|c|c|c|c|c|c|c|c|c|}
\hline & Parameter & Unit & $\mathrm{N}$ & Mean & Median & Minimum & Maximum & Standard deviation \\
\hline \multirow[t]{13}{*}{ Precipitation } & $\mathrm{EC}$ & $\mu \mathrm{S} \cdot \mathrm{cm}^{-1}$ & 41 & 71 & 61 & 12 & 162 & 36 \\
\hline & $\mathrm{pH}$ & - & 41 & 5.20 & 5.20 & 4.45 & 5.82 & 0.56 \\
\hline & $\mathrm{HCO}_{3}^{-}$ & $\mathrm{mg} \cdot \mathrm{dm}^{-3}$ & 41 & 5.73 & 4.15 & 0.73 & 17.09 & 4.39 \\
\hline & $\mathrm{Cl}^{-}$ & $\mathrm{mg} \cdot \mathrm{dm}^{-3}$ & 41 & 4.06 & 2.75 & 0.70 & 18.63 & 3.86 \\
\hline & $\mathrm{NO}_{2}^{-}$ & $\mathrm{mg} \cdot \mathrm{dm}^{-3}$ & 41 & 0.96 & 0.67 & $<0.01$ & 2.93 & 0.78 \\
\hline & $\mathrm{NO}_{3}^{-}$ & $\mathrm{mg} \cdot \mathrm{dm}^{-3}$ & 41 & 4.52 & 3.71 & $<0.01$ & 16.49 & 3.50 \\
\hline & $\mathrm{SO}_{4}{ }^{2-}$ & $\mathrm{mg} \cdot \mathrm{dm}^{-3}$ & 41 & 8.12 & 5.62 & $<0.01$ & 24.51 & 5.79 \\
\hline & $\mathrm{Na}^{+}$ & $\mathrm{mg} \cdot \mathrm{dm}^{-3}$ & 41 & 2.36 & 1.73 & $<0.01$ & 12.86 & 2.49 \\
\hline & $\mathrm{NH}_{4}^{+}$ & $\mathrm{mg} \cdot \mathrm{dm}^{-3}$ & 41 & 2.46 & 2.12 & $<0.01$ & 7.92 & 1.75 \\
\hline & $\mathrm{K}^{+}$ & $\mathrm{mg} \cdot \mathrm{dm}^{-3}$ & 41 & 2.85 & 1.62 & 0.01 & 22.95 & 4.18 \\
\hline & $\mathrm{Mg}^{2+}$ & $\mathrm{mg} \cdot \mathrm{dm}^{-3}$ & 41 & 0.25 & 0.17 & 0.05 & 0.97 & 0.18 \\
\hline & $\mathrm{Ca}^{2+}$ & $\mathrm{mg} \cdot \mathrm{dm}^{-3}$ & 41 & 2.15 & 1.50 & 0.14 & 6.93 & 1.70 \\
\hline & $\delta^{15} \mathrm{~N}_{\mathrm{N} 2 \text {-Air }}\left(\mathrm{NH}_{4}{ }^{+}\right)$ & $\%$ & $29 *$ & 2.1 & 1.3 & -11.5 & 18.5 & 6.8 \\
\hline Air & Air temperature & ${ }^{\circ} \mathrm{C}$ & 41 & 10.6 & 10.0 & -11.0 & 26.0 & 8.4 \\
\hline
\end{tabular}

* For the isotope analysis we only considered rainwater samples whose volume was greater than 11 or generated a sufficient ionization current that allowed a proper analysis. In total we analysed 29 samples out of 41 collected 
10,2010 ) with a mean value of $4.1 \mathrm{mg} \cdot \mathrm{L}^{-1}$ (median: $2.8 \mathrm{mg} \cdot \mathrm{L}^{-1}$ ) and $\mathrm{HCO}_{3}{ }^{-}$from $0.7 \mathrm{mg}$. $\mathrm{L}^{-1}$ (December 25, 2010) to $17.1 \mathrm{mg} \cdot \mathrm{L}^{-1}$ (March 3, 2010) with a mean value of $5.7 \mathrm{mg} \cdot \mathrm{L}^{-1}$ (median: $4.2 \mathrm{mg} \cdot \mathrm{L}^{-1}$ ) (Table 1$)$.

\subsection{Nitrogen isotope composition $\left(\delta^{15} \mathrm{~N}\right)$ of $\mathrm{NH}_{4}^{+}$}

$\delta^{15} \mathrm{~N}$ of $\mathrm{NH}_{4}{ }^{+}$showed large fluctuations during the study period from -11.5 (January 28) to + $18.5 \%$ (August 31 ) with an average value of $2.1 \%$ (median: $1.3 \%$ ) (Table 1).

\section{Discussion}

\subsection{Sources and process controlling the chemical composition of rainwater}

The chemical compositions of precipitation showed during 2010 a significant variability with time (Figs. 2 and 3) that may indicate that either one or different processes are involved or/and that this/these process(es) vary(ies) with time. PCA can help alleviate this difficulty by distinguishing processes that control the chemical composition of rainwater (Zhang et al. 1992) as well as help estimate the intensity of these processes by the study of factor scores. Extreme negative values $(<-1)$ indicate that the specific processes that each factor represents do not affect samples. In contrast, positive values $(>+1)$ indicate they are strongly impacted by these processes. Values between -1 and +1 define the "mixing zone" of individual processes (Manly 1998; Jolliffe 2002).

PCA, in our case, explains $82 \%$ of the observed chemical variations (Table 2). The remaining $18 \%$ were considered as "random noise" that can not be interpreted using this technique (Drever 1997; Manly 1998). Results suggest that chemical and isotope compositions of our precipitation are formed/controlled by at least three distinct factors (Table 2) interpreted as natural and anthropogenic processes or a mixing of both.

\subsubsection{Factor 1}

Factor 1 accounted for nearly $40 \%$ of the total variance, had high positive factors for EC, $\mathrm{HCO}_{3}{ }^{-}, \mathrm{NO}_{3}{ }^{-}, \mathrm{NO}_{2}{ }^{-}, \mathrm{NH}_{4}{ }^{+}$and $\mathrm{SO}_{4}{ }^{2-}$ (Table 2) probably hinting that they may have a common origin. Strong correlation between mineral forms of nitrogen and sulphate ions is observed in many rainwater studies worldwide (e.g. Plaisance et al. 1997; Cao et al. 2009; Calvo et al. 2010) and usually is interpreted by the authors as a mixing of emissions from different anthropogenic sources.

$\mathrm{NO}_{2}{ }^{-}$and $\mathrm{NO}_{3}{ }^{-}$yielded maximum concentrations in spring at the beginning of vegetative season (Figs. 2 and 3) with values of $2.9 \mathrm{mg} \cdot \mathrm{L}^{-1}$ and $16.5 \mathrm{mg} \cdot \mathrm{L}^{-1}$, respectively (Table 1; Supplementary Materials; Fig. 2). These concentrations are unexpectedly higher than those reported for the Lower Silesia Region and rural areas in other countries (Cao et al. 2009; Wang and Han 2011). For 2010, the Voivodeship Inspectorate for Environmental Protection for whole voivodeship (VIfEP Report 2010) reports combined $\left(\mathrm{NO}_{2}{ }^{-}+\mathrm{NO}_{3}{ }^{-}\right)$concentrations from $0.02 \mathrm{mg} \cdot \mathrm{L}^{-1}$ to $3.6 \mathrm{mg} \cdot \mathrm{L}^{-1}$, still lower than our data obtained in Wrocław. Annual averages of $\mathrm{NO}_{3}{ }^{-}$concentrations in the Sudety Mountains (SW Poland) ranged from 1.9 to $2.7 \mathrm{mg} \cdot \mathrm{L}^{-1}$ between 1988 and 1992 (Kmieć et al. 1994) and from 0.6 to $1.5 \mathrm{mg} \cdot \mathrm{L}^{-1}$ in the vicinity of Wroclaw between 2002 and 2010 (Czyżyk and Rajmund 2011). Our $\mathrm{NH}_{4}{ }^{+}$concentrations in 

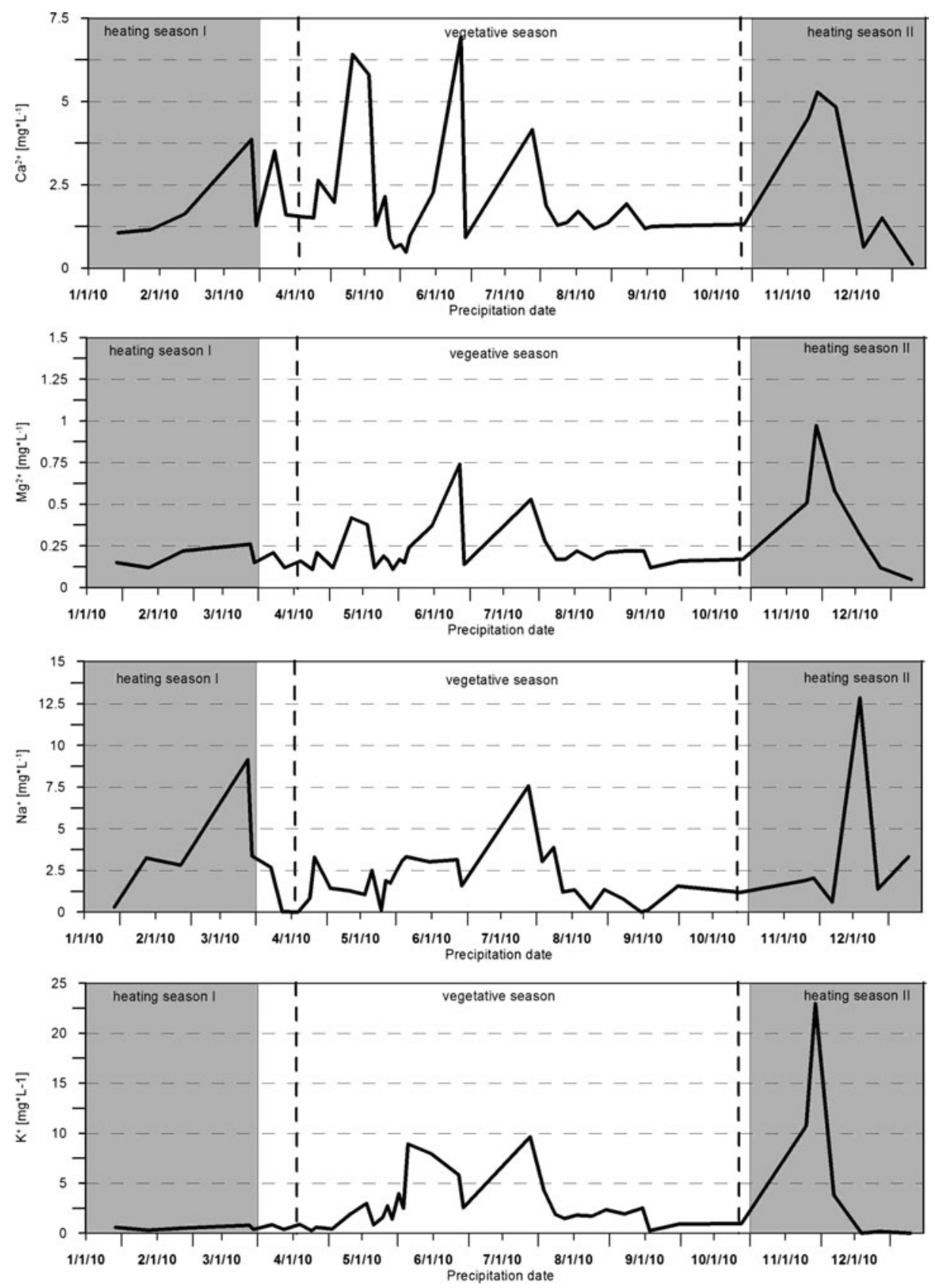

Fig. 2 Temporal variability of concentration of anions in precipitation water sampled in Wrocław in 2010

precipitation ranged from $<0.01 \mathrm{mg} \cdot \mathrm{L}^{-1}$ to $7.9 \mathrm{mg} \cdot \mathrm{L}^{-1}$ in 2010 . Kmieć et al. (1994) reported for $1994 \mathrm{NH}_{4}{ }^{+}$values from 2.3 to $3.9 \mathrm{mg} \cdot \mathrm{L}^{-1}$ similar to the highest values we observed during the vegetative season (Fig. 4). Those spring maximum concentrations of $\mathrm{N}$ mineral forms may be related to the plants biological activity caused by the application of fertilizer onto 

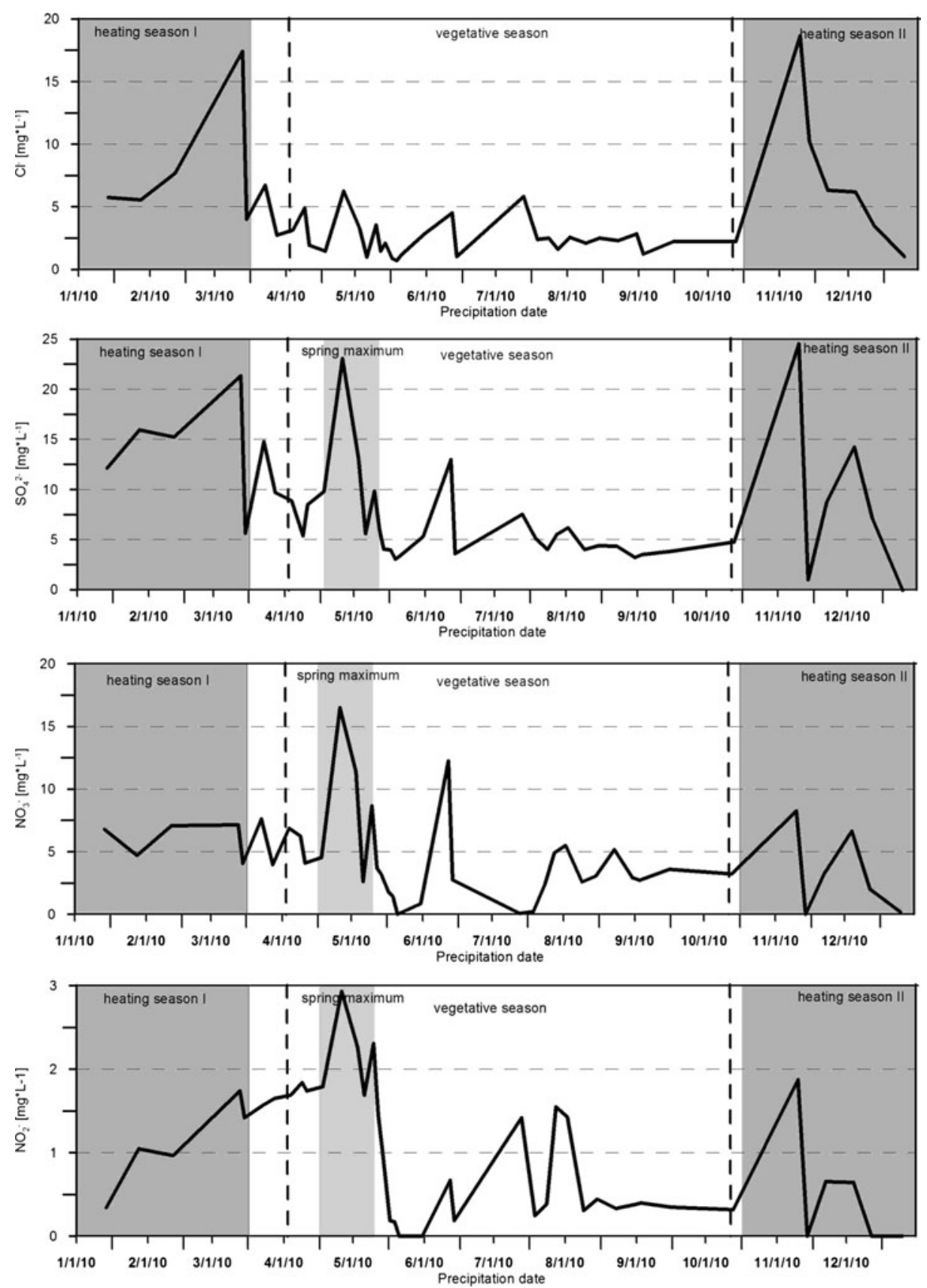

Fig. 3 Temporal variability of concentration of cations in precipitation water sampled in Wrocław in 2010

agricultural fields during spring (Freyer 1978a, b). The concomitant $\mathrm{NH}_{4}{ }^{+}$peak may be related to an increase in the rate of $\mathrm{NH}_{4}{ }^{+}$volatilization from agricultural fields (fertilized with manure and/or urea). $\mathrm{NH}_{4}{ }^{+}$volatilization results from the temperature-controlled bacterial enzymatic 
Table 2 Results of the Principal Component Analysis (PCA) for precipitation water collected in Wrocław in 2010

\begin{tabular}{|c|c|c|c|}
\hline Parameter & Factor 1 & Factor 2 & Factor 3 \\
\hline $\mathrm{EC}\left[\mu \mathrm{S} \cdot \mathrm{cm}^{-1}\right]$ & 0.71 & 0.50 & 0.48 \\
\hline $\mathrm{HCO}_{3}{ }^{-}\left[\mathrm{mg} \cdot \mathrm{L}^{-1}\right]$ & 0.78 & -0.11 & -0.02 \\
\hline $\mathrm{Cl}^{-}\left[\mathrm{mg} \cdot \mathrm{L}^{-1}\right]$ & 0.36 & 0.47 & 0.66 \\
\hline $\mathrm{NO}_{2}^{-}\left[\mathrm{mg} \cdot \mathrm{L}^{-13}\right]$ & 0.87 & -0.08 & 0.03 \\
\hline $\mathrm{NO}_{3}{ }^{-}\left[\mathrm{mg} \cdot \mathrm{L}^{-1}\right]$ & 0.89 & 0.07 & 0.07 \\
\hline $\mathrm{SO}_{4}{ }^{2-}\left[\mathrm{mg} \cdot \mathrm{L}^{-1}\right]$ & 0.78 & 0.13 & 0.53 \\
\hline $\mathrm{Na}^{+}\left[\mathrm{mg} \cdot \mathrm{L}^{-1}\right]$ & -0.11 & -0.00 & 0.86 \\
\hline $\mathrm{NH}_{4}^{+}\left[\mathrm{mg} \cdot \mathrm{L}^{-1}\right]$ & 0.75 & 0.13 & -0.26 \\
\hline $\mathrm{K}^{+}\left[\mathrm{mg} \cdot \mathrm{L}^{-1}\right]$ & -0.26 & 0.90 & 0.03 \\
\hline $\mathrm{Mg}^{2+}\left[\mathrm{mg} \cdot \mathrm{L}^{-1}\right]$ & 0.07 & 0.96 & 0.12 \\
\hline $\mathrm{Ca}^{2+}\left[\mathrm{mg} \cdot \mathrm{L}^{-1}\right]$ & 0.56 & 0.76 & 0.05 \\
\hline Factor contribution $[\%]$ & 40 & 26 & 16 \\
\hline
\end{tabular}

Bold text indicates values considered as significant $(-0.6 /+0.6)$

activity, where the urease enzyme catalyses the release of $\mathrm{NH}_{4}{ }^{+}$from urea (Torello and Wehner 1983). Therefore an increase in the $\mathrm{NH}_{4}^{+}$volatilisation rate is expected during spring especially when considering other local conditions: predominance of sandy soils with expected low cations exchange capacities, high soil moisture, periodical flooding, crop residues (Ernst and Massey 1960; Torello and Wehner 1983; Tomassi-Morawiec et al. 1998).

$\mathrm{SO}_{4}{ }^{2-}$ concentrations, from $<0.01 \mathrm{mg} \cdot \mathrm{L}^{-1}$ to $24.5 \mathrm{mg} \cdot \mathrm{L}^{-1}$, were higher during heating periods (related to fossil fuels combustion) than during the vegetative season. An elevated spring concentration pick was also observed (Fig. 2). Similarly to $\mathrm{NO}_{2}{ }^{-}$and $\mathrm{NO}_{3}{ }^{2-} \mathrm{SO}_{4}{ }^{2-}$ concentrations were higher in Wrockaw than in the whole voivodeship $(0.3$ to $15.1 \mathrm{mg}$. $\mathrm{L}^{-1}$; VIfEP Report 2010). In the near Sudety Mountains $\mathrm{SO}_{4}{ }^{2-}$ concentrations in precipitation range from 9.1 to $15.4 \mathrm{mg} \cdot \mathrm{L}^{-1}$ (Kmieć et al. 1994) and from 3.1 to $9.4 \mathrm{mg} \cdot \mathrm{L}^{-1}$ in the vicinity of Wroclaw (Czyżyk and Rajmund 2011). Additionally, during the heating season II two higher concentrations of $\mathrm{NO}_{3}{ }^{-}$and $\mathrm{NO}_{2}{ }^{-}$(coupled to high $\mathrm{SO}_{4}{ }^{2-}$ episodes) were observed (Fig. 1). Analysis of the variability of $\mathrm{NO}_{3}{ }^{-}, \mathrm{NO}_{2}{ }^{-}, \mathrm{NH}_{4}{ }^{+}, \mathrm{SO}_{4}{ }^{2-}$ ions and PCA correlation shows that in Wroclaw they likely result from a mixing of two or three main anthropogenic sources: 1) application of fertilizers, 2) combustion of fossil fuels and 3) emissions from local Osobowice sewage irrigation fields. Though processes have not been fully characterised, $\mathrm{SO}_{4}{ }^{2-}, \mathrm{NO}_{3}{ }^{-}$and $\mathrm{NH}_{4}{ }^{+}$can also be produced as secondary inorganic aerosols (SIA) trough photochemical reactions between gaseous pollutants and primary aerosols (Baker and Scheff 2007; Behera and Sharma 2011). Still, multiple atmospheric reactions may explain the strong correlation existing between these ions and ultimately play a role in the formation of the chemical composition of precipitation in Wrocław. Analysis of factor 1 scores shows that highest values $(>1)$ are observed during the vegetative season (spring maximum; Fig. 4), indicating that these processes are dominant during this period. During the rest of the year they are contributing less ("mixing zone" in Fig. 4). Processes represented by factor 1 largely determine the rainwater mineralization as evidenced by its strong correlation with both EC and $\mathrm{HCO}_{3}{ }^{-}$concentrations. 

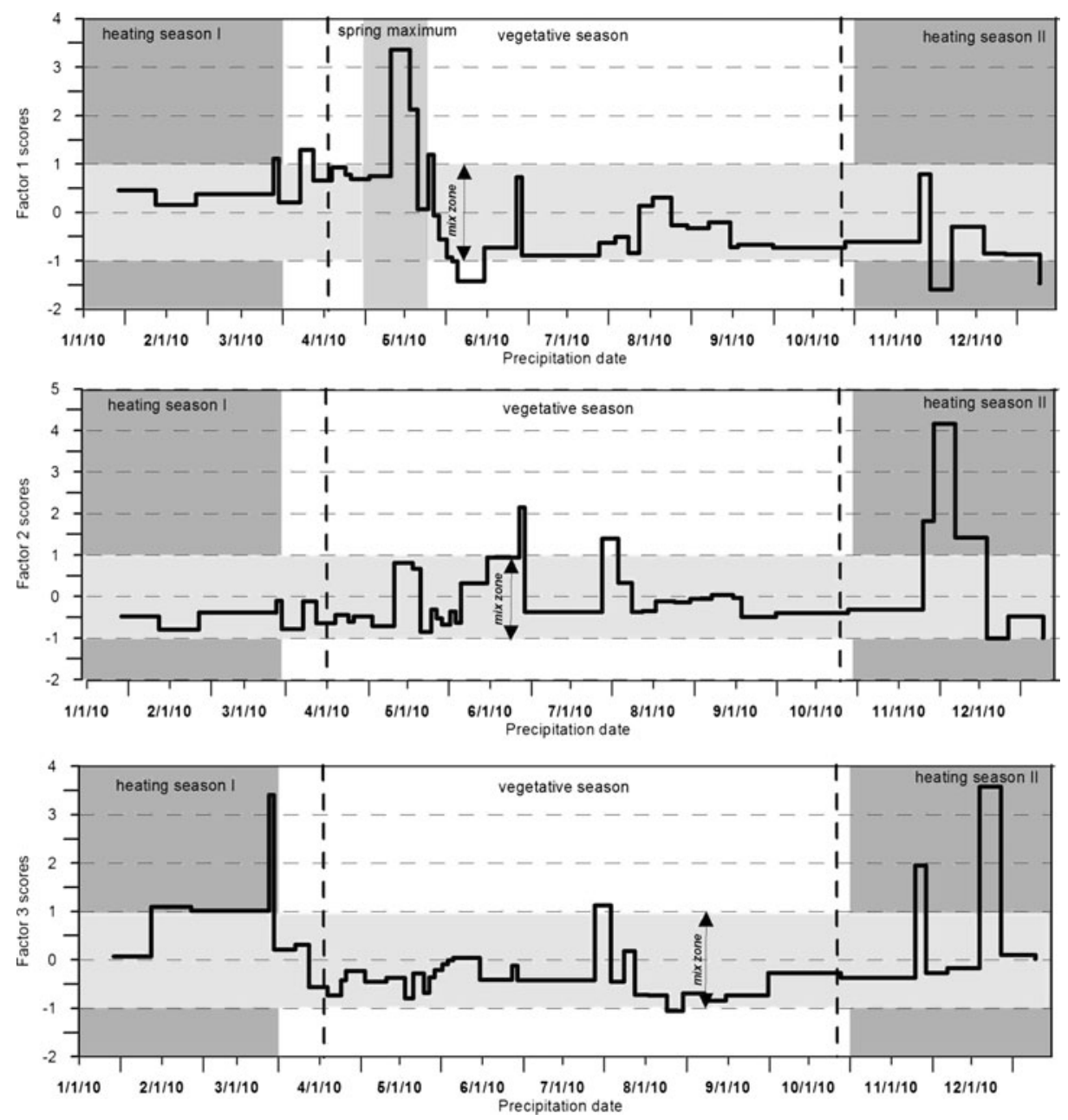

Fig. 4 Temporal variability of factor scores calculated via PCA for precipitation water sampled in Wrocław in 2010

\subsubsection{Factor 2}

Factor 2 accounted for $26 \%$ of the total variance and had high positive factor loadings for $\mathrm{K}^{+}$, $\mathrm{Ca}^{2+}$ and $\mathrm{Mg}^{2+}$. The fact that the PCA identifies these components as a factor suggests that their main sources in precipitation are probably distinct than those for $\mathrm{NO}_{3}{ }^{-}, \mathrm{NO}_{2}{ }^{-}, \mathrm{NH}_{4}{ }^{+}$and $\mathrm{SO}_{4}{ }^{2-} \cdot \mathrm{Ca}^{2+}$ concentrations, obtained in this study, ranged from $0.1 \mathrm{mg} \cdot \mathrm{L}^{-1}$ to $6.9 \mathrm{mg} \cdot \mathrm{L}^{-1}$ consistent with concentrations reported by VIfEP $\left(0.1-7.1 \mathrm{mg} \cdot \mathrm{L}^{-1}\right)$, Kmieć et al. $(1994 ; 2.0$ to $\left.2.7 \mathrm{mg} \cdot \mathrm{L}^{-1}\right)$ and Czyżyk and Rajmund (2011; 0.5 to $2.5 \mathrm{mg} \cdot \mathrm{L}^{-1}$. VIfEP reports slightly higher $\mathrm{Mg}^{2+}$ concentrations $\left(0.1-1.6 \mathrm{mg} \cdot \mathrm{L}^{-1}\right)$ than those measured in this study $\left(0.1-1.0 \mathrm{mg} \cdot \mathrm{L}^{-1}\right)$. Previous studies (1988-1992 and 2002-2010) yielded lower concentration ranges for $\mathrm{Mg}^{2+}$, from 0.3 to $0.5 \mathrm{mg} \cdot \mathrm{L}^{-1}$ and from 0.1 to $0.4 \mathrm{mg} \cdot \mathrm{L}^{-1}$, respectively (Kmieć et al. 1994 and Czyżyk and Rajmund 2011). $\mathrm{K}^{+}$concentrations as high as $22.9 \mathrm{mg} \cdot \mathrm{L}^{-1}$ significantly higher 
than those measured by VIfEP $\left(0.1-2.9 \mathrm{mg} \cdot \mathrm{L}^{-1}\right)$ as well as in previous studies: 1.1 to $3.8 \mathrm{mg}$. $\mathrm{L}^{-1}$ (Kmieć et al. 1994) and 0.5 to $2.7 \mathrm{mg} \cdot \mathrm{L}^{-1}$ (Czyżyk and Rajmund 2011).

For $\mathrm{K}^{+}, \mathrm{Ca}^{2+}$ and $\mathrm{Mg}^{2+}$ (Fig. 3) and factor 2 scores (Fig. 4) the highest values were observed 2-3 times during the vegetative season and once during the heating season II. The rest of the year, values plotted in the "mixing zone" (Fig. 4). These ions can have either a crustal $\left(\mathrm{Ca}^{2+}, \mathrm{Mg}^{2+}, \mathrm{K}^{+}\right.$are present in weathering products minerals) or anthropogenic origin (e.g. vehicle roadside dust, industrial aerosol) (Plaisance et al. 1997; Ali et al. 2004; Cao et al. 2009; Wang and Han 2011). Once emitted in the atmosphere they can be flushed following interaction with rainwater. But we observed no significant correlation between the volume of precipitation and these ions concentrations except once during the heating season II. Low precipitation can also lead to an increase in their corresponding concentrations. $\mathrm{K}^{+}, \mathrm{Mg}^{2+}$ and $\mathrm{Ca}^{2+}$ are ubiquitous in fertilizers, including ammonium nitrate $\left(\mathrm{NH}_{4} \mathrm{NO}_{3}\right)$ and ammonium sulphate $\left(\left(\mathrm{NH}_{4}\right)_{2} \mathrm{SO}_{4}\right)$, which probably represent one of these ions sources in factor 1 . In particular the fact that potassium fertilizers, such as $\mathrm{KCl}$ and $\mathrm{K}_{2} \mathrm{SO}_{4}$, are often applied or reapplied in autumn and winter season in Europe (Crous et al. 2008; Hejcman et al. 2012; Shield et al. 2014) may explain the $\mathrm{K}^{+}$peak observed in autumn (Fig. 2). Potassium ions also tend to accumulate in top layers in fertilized soils, which can facilitate their transfer to the atmosphere during soil dust suspension (Shield et al. 2014). This suggests that factor 2 may represent a mixing of two processes: 1) natural and anthropogenic dusts emissions and 2) application of fertilizers (containing $\mathrm{K}^{+}, \mathrm{Ca}^{2+}$ and $\mathrm{Mg}^{2+}$ ) to tillage soils. The absence of correlation between components from PCA factors 1 and 2 also favours volatilisation during application of fertilizers, irrigation fields activity as the main source of $\mathrm{NH}_{4}{ }^{+}$as further field tilling is expected to generate dust, the main component of factor 2 .

\subsubsection{Factor 3}

Factor 3 accounted for $16 \%$ of the total variance and yielded high positive factor values for $\mathrm{Na}^{+}$and $\mathrm{Cl}^{-}$, that probably represent marine aerosols and dry deposition (Plaisance et al. 1997; Błaś et al. 2010; Calvo et al. 2010). $\mathrm{Na}^{+}$concentration ranged from $<0.01$ to $12.9 \mathrm{mg} \cdot \mathrm{L}^{-1}$ and $\mathrm{Cl}^{-}$from $0.7 \mathrm{mg} \cdot \mathrm{L}^{-1}$ to $18.6 \mathrm{mg} \cdot \mathrm{L}^{-1}$, higher than the values measured by VIfEP in Wrocław and the whole voivodeship ( $\mathrm{Na}^{+}$from 0.01 to $2.6 \mathrm{mg} \cdot \mathrm{L}^{-1}$ and $\mathrm{Cl}^{-}$from 0.05 to $6.5 \mathrm{mg} \cdot \mathrm{L}^{-1}$ ) and from previous studies: $\mathrm{Na}^{+}$from 1.5 to $1.9 \mathrm{mg} \cdot \mathrm{L}^{-1}, \mathrm{Cl}^{-}$from 3.8 to $5.0 \mathrm{mg} \cdot \mathrm{L}^{-1}$ (Kmieć et al. 1994) and $\mathrm{Na}^{+}$from 0.9 to $3.2 \mathrm{mg} \cdot \mathrm{L}^{-1}, \mathrm{Cl}^{-}$from 3.1 to $5.7 \mathrm{mg} \cdot \mathrm{L}^{-1}$ (Czyżyk and Rajmund 2011). The median value for the $\mathrm{Cl} / \mathrm{Na}$ ratio in precipitation was above 1.17 , the typical for seawater, but along the year extremely high (367) and low $(0.15) \mathrm{Cl} / \mathrm{Na}$ ratios were also observed. Analysis of the variability of $\mathrm{Na}^{+}, \mathrm{Cl}^{-}$and factor 3 values suggest that the processes represented by factor 3 affected the composition of precipitation throughout the year but dominated during the winter periods.

\subsection{Origin of $\mathrm{NH}_{4}^{+}$concentrations and $\delta^{15} \mathrm{~N}\left(\mathrm{NH}_{4}{ }^{+}\right)$isotope compositions}

The $\mathrm{NH}_{4}^{+}$concentrations ranged from $<0.01$ to $7.9 \mathrm{mg} \cdot \mathrm{L}^{-1}$ with an average value of $2.5 \pm$ $1.8 \mathrm{mg} \cdot \mathrm{L}^{-1}$ and $\delta^{15} \mathrm{~N}\left(\mathrm{NH}_{4}{ }^{+}\right)$values ranged from -11.5 to $18.5 \%$ with an average value of $2.1 \pm$ $6.8 \%$, which both represent wider ranges than those obtained by other authors (Fig. 6) (Hoering 1957; Moore 1974; Freyer 1978a, b; Heaton 1987; Paerl and Fogel 1994; Gao 2002). This large fluctuation of $\left.\delta^{15} \mathrm{~N} \mathrm{NH}_{4}{ }^{+}\right)$may indicate that several sources of nitrogen compounds are involved or that secondary processes are significantly fractionating initial isotope compositions. 
Temporal variations of $\mathrm{NH}_{4}{ }^{+}$concentrations in precipitation clearly identify two distinct periods corresponding to two peaks in $\mathrm{NH}_{4}{ }^{+}$concentrations (Fig. 5): (i) early spring, and (ii) early autumn. In both cases the maximum $\mathrm{NH}_{4}{ }^{+}$concentration is probably due to (i) increased application of fertilizers in local agricultural fields 1) at the beginning of the vegetation period and then in autumn for autumn-sown cereal or 2) biological activity at the local Osobowice sewage irrigation fields. The variations in $\mathrm{NH}_{4}{ }^{+}$concentrations do not seem to correlate with the corresponding $\delta^{15} \mathrm{~N}\left(\mathrm{NH}_{4}{ }^{+}\right)$as we are observing a rough ${ }^{15} \mathrm{~N}$ enrichment along the whole season (Fig. 5).

The lack of simple correlation of $\mathrm{NH}_{4}{ }^{+}$concentrations $\left(1 / \mathrm{NH}_{4}{ }^{+}\right.$ratio) with the corresponding $\delta^{15} \mathrm{~N}\left(\mathrm{NH}_{4}{ }^{+}\right)$were confirmed by statistical tests $(\mathrm{R}=-0.07$ and $\mathrm{R}=-0.08$, respectively, $p<0.05)$. This is probably caused by a complex atmospheric open system controlled by numerous intricate nitrogen sources, conditions (e.g. temperature, pressure) and secondary processes that may fractionate nitrogen isotopes. However, our data show positive relations between the daily average temperature and $\delta^{15} \mathrm{~N}\left(\mathrm{NH}_{4}{ }^{+}\right)$, and daily average temperature and $\mathrm{NH}_{4}{ }^{+}$concentrations (Fig. 5), confirmed by significant statistical correlations $(\mathrm{R}=0.38$ and $\mathrm{R}=$ 0.70 respectively; $p<0.05)$. Figure 6 reports variations of $\mathrm{NH}_{4}{ }^{+}$concentrations and $\left.\delta^{15} \mathrm{~N} \mathrm{NH}_{4}{ }^{+}\right)$for each identified 3 seasons (heating I, vegetation and heating II). Results indicate that all data can be explained by at least the three following end-members (two at low $\mathrm{NH}_{4}{ }^{+}$concentrations and one dominant at $\mathrm{NH}_{4}{ }^{+}$concentrations higher than $\left.8 \mathrm{mg} \cdot \mathrm{L}^{-1}\right)$ : 1) Low $\mathrm{NH}_{4}^{+}$and high $\left.\delta^{15} \mathrm{~N}(>20 \%), 2\right)$ low $\mathrm{NH}_{4}^{+}$and low $\delta^{15} \mathrm{~N}(<15 \%$ o) and 3$)$ high $\mathrm{NH}_{4}^{+}$ $\left(>8 \mathrm{mg} \cdot \mathrm{L}^{-1}\right)$ and a $\delta^{15} \mathrm{~N}$ around $0 \%$.

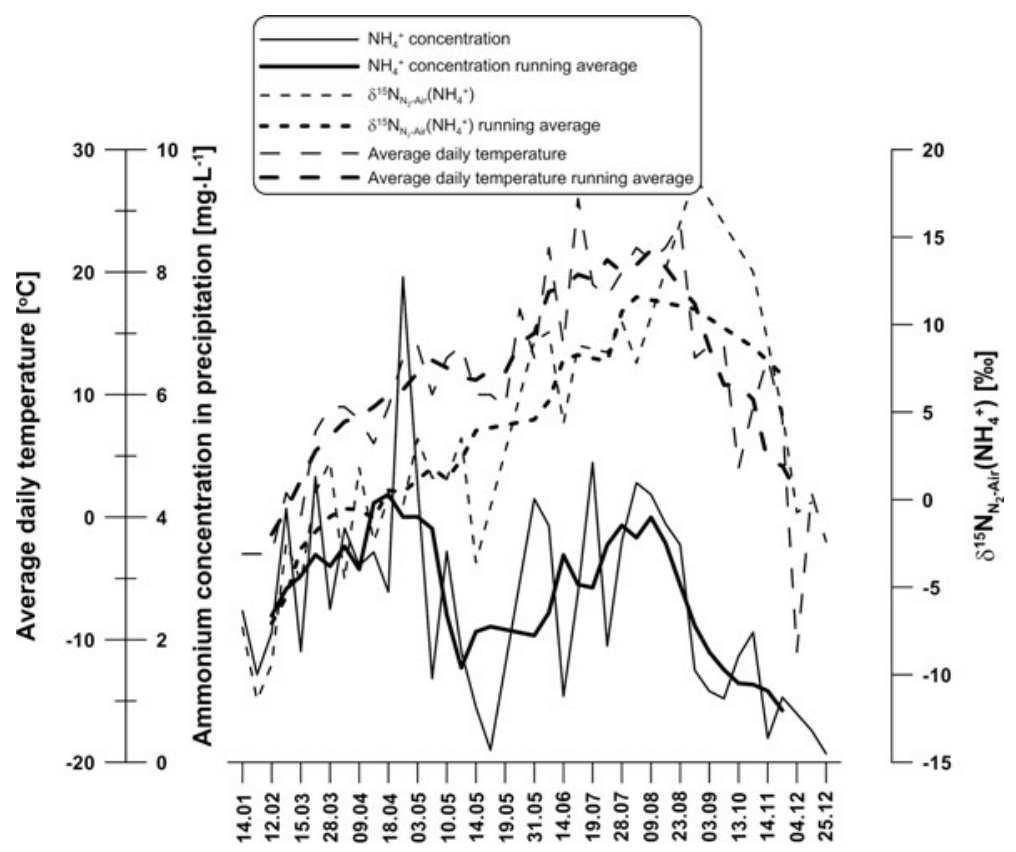

Sampling date in 2010

Fig. $5 \delta^{15} \mathrm{~N}_{\mathrm{N} 2 \text {-Air }}\left(\mathrm{NH}_{4}{ }^{+}\right), \mathrm{NH}_{4}{ }^{+}$concentration in precipitation and air temperature during sampling period. Air temperature values from www.wunderground.com 


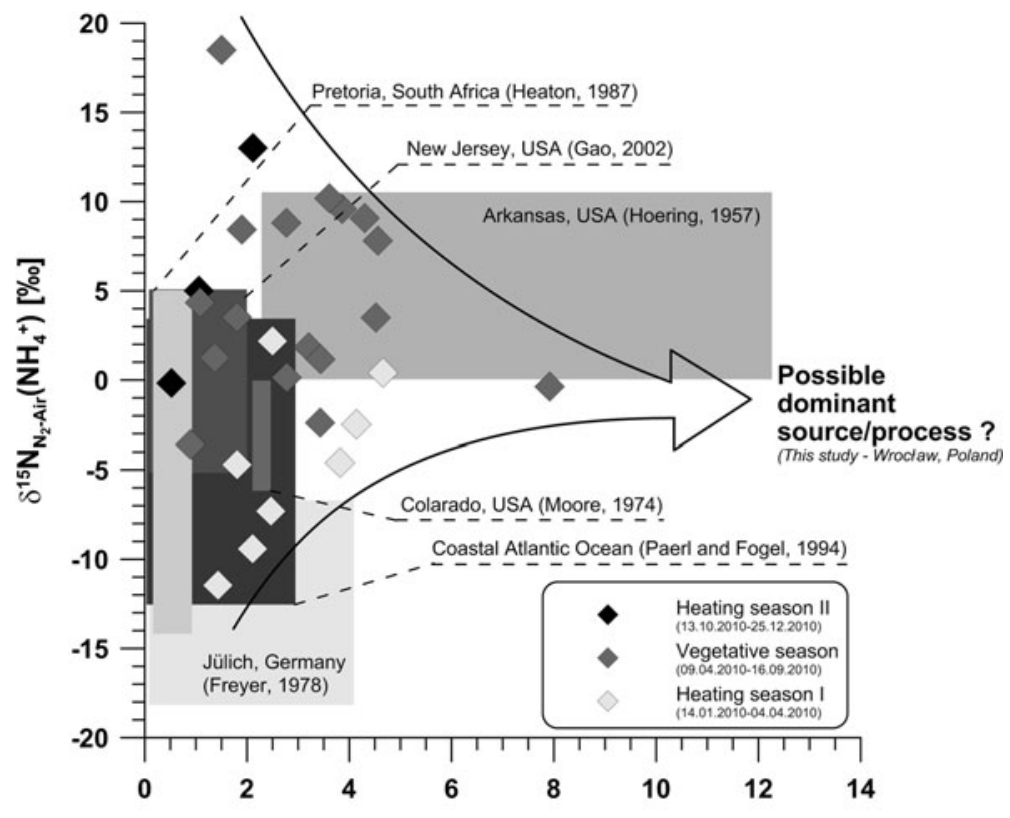

Ammonium concentration in precipitation $\left[\mathrm{mg} \cdot \mathrm{L}^{-1}\right]$

Fig. 6 Relationship between ammonium concentration and $\delta^{15} \mathrm{~N}_{\mathrm{N} 2-\mathrm{Air}}\left(\mathrm{NH}_{4}{ }^{+}\right)$in precipitation. Values of ammonium concentration and $\delta^{15} \mathrm{~N}_{\mathrm{N} 2-\mathrm{Air}}\left(\mathrm{NH}_{4}{ }^{+}\right)$values are from: Hoering 1957; Moore 1974; Freyer 1978a, b; Heaton 1987; Paerl and Fogel 1994 and Gao 2002

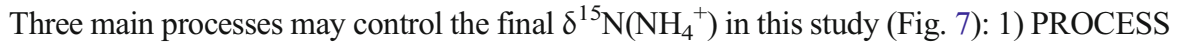
1: equilibrium fractionation between $\mathrm{NH}_{3}$ and $\mathrm{NH}_{4}^{+}$; 2) PROCESS 2: kinetic exchange reactions between $\mathrm{NH}_{3}$ and $\mathrm{NH}_{4}^{+}$; and 3) PROCESS 3: exchange reactions between atmospheric $\mathrm{NH}_{4}{ }^{+}$in salt aerosols and $\mathrm{NH}_{4}{ }^{+}$in precipitation. Variations of air temperature with $\delta^{15} \mathrm{~N} \mathrm{NH}_{4}{ }^{+}$) in precipitation (Fig. 7a) discriminate samples into two distinct groups depending on the season: (I) vegetative and (II) heating seasons.

If we assume an equilibrium isotope fractionation between $\mathrm{NH}_{3}$ and $\mathrm{NH}_{4}{ }^{+}$in precipitation we can try to estimate the $\delta^{15} \mathrm{~N}$ of $\mathrm{NH}_{3}$ from which $\mathrm{NH}_{4}{ }^{+}$was formed. Volatilization of urea (e.g. manure) in soils follows a Rayleigh distillation that is highly favouring ${ }^{15} \mathrm{~N}$, resulting in $\Delta^{15} \mathrm{~N}$ in volatilized $\mathrm{NH}_{3}$ around $35 \%$ (Frank et al. 2004) and even 30-60\%o (Högberg 1997; Robinson 2001). Similarly, the process of volatilizing fertilizers (with $\delta^{15} \mathrm{~N}$ around $0.2 \%$; Bateman and Kelly 2007) produces $\mathrm{NH}_{3}$ with $\delta^{15} \mathrm{~N}$ between -48.0 and $-36.3 \%$, which represents a similar nitrogen isotope fractionation $(\Delta)$ as for urea. However, isotopically describing the opposite process of dissolving $\mathrm{NH}_{3}$ in atmospheric water into $\mathrm{NH}_{4}{ }^{+}$is probably more complicated. Still, we can estimate the $\delta^{15} \mathrm{~N}$ of potential sources atmospheric $\mathrm{NH}_{3}$

Fig. 7 Possible explanations of precipitation ammonium origin basing of $\left.\delta^{15} \mathrm{~N}_{(} \mathrm{NH}_{4}{ }^{+}\right)$. a Fractionation equation from Scalan 1958. b Vehicle exhaust, cow waste, volatilized fertilizer levels from Felix et al. 2013 and brown and hard coal level from Freyer 1978a, b. c Possible kinetic exchange reactions from Freyer 1978a, b and Heaton 1987; $\delta^{15} \mathrm{~N}\left(\mathrm{NH}_{4}{ }^{+}\right)$levels for tropospheric aerosols from Moore 1977, fertilizer from Shearer et al. 1974 and for soil $\mathrm{NH}_{4}{ }^{+}$from Freyer $1978 \mathrm{a}$, b. Process 1 - Measured $\delta^{15} \mathrm{~N}\left(\mathrm{NH}_{4}^{+}\right)$values were converted to theoretical

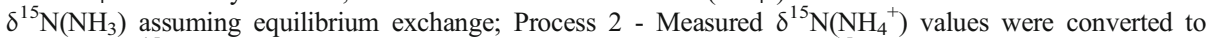

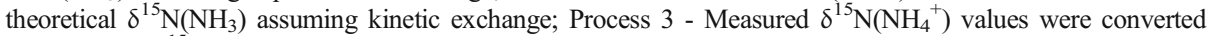
to theoretical $\left.\delta^{15} \mathrm{~N} \mathrm{NH}_{4}{ }^{+}\right)$assuming atmospheric solid $\mathrm{NH}_{4}{ }^{+}$exchange 


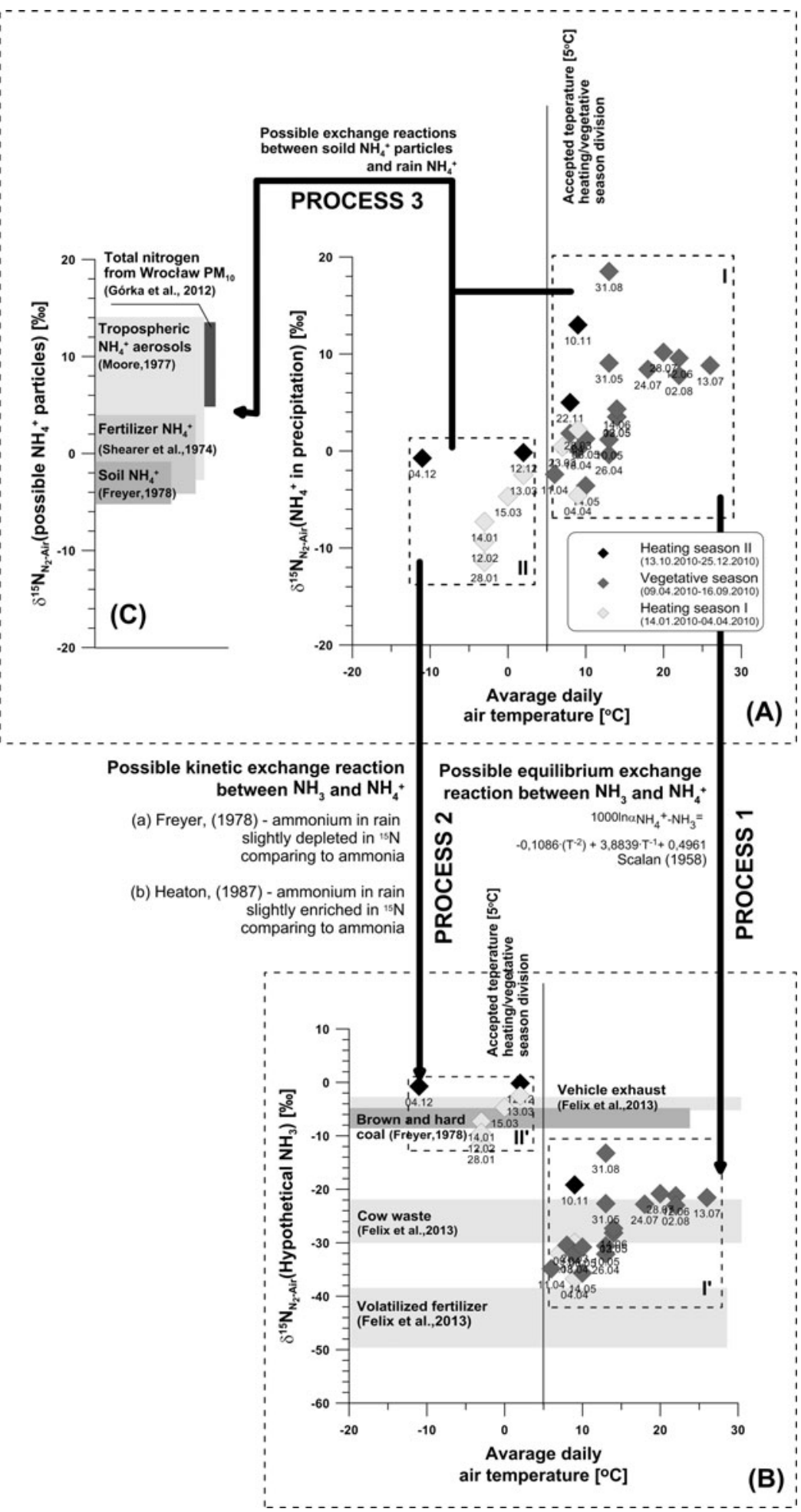


sources from the values of $\delta^{15} \mathrm{~N}\left(\mathrm{NH}_{4}{ }^{+}\right)$values and daily air temperature using the $\mathrm{NH}_{4}{ }^{+}-\mathrm{NH}_{3}$ equation described in Scalan et al. (1958) and in Busigny and Bebout (2013). Results give a range of $\delta^{15} \mathrm{~N}\left(\mathrm{NH}_{3}\right)$ from -35.0 to $-13.2 \%$ sample group I during vegetative season (Fig. $7 \mathrm{~b}$ ) that implies involving two main sources of $\left.\mathrm{NH}_{3}: 1\right)$ animal waste with $\delta^{15} \mathrm{~N}\left(\mathrm{NH}_{3}\right)$ values from -28.5 to $-22.8 \%$, (Felix et al. 2013) and fertilizers with $\delta^{15} \mathrm{~N}_{\left(\mathrm{NH}_{3}\right)}$ values from -48.0 to $-36.3 \%$, (Felix et. al. 2013). While our isotope data do not contradict fertilisers or sewage irrigation fields as the main sources of atmospheric $\mathrm{NH}_{3}$ in Wroclaw during the vegetative season, it does not unambiguously comfort this hypothesis as $\mathrm{NH}_{3}$ volatilisation from fertilizer, manure, urea produces overlapping $\delta^{15} \mathrm{~N}\left(\mathrm{NH}_{3}\right)$ ranges. If PROCESS 1 is actually controlling the atmospheric budget of $\mathrm{NH}_{3}$ in the atmosphere of Wroclaw it would imply that during the vegetative season fertilisers and manure are the dominant sources of $\mathrm{NH}_{3}$, compared to vehicle and industrial emissions. For samples in group II that correspond to heating seasons I \& II (Fig. 7a) we cannot use the Scalan equation as it is not suited for temperatures below $0{ }^{\circ} \mathrm{C}$. At these temperatures a nitrogen exchange between $\mathrm{NH}_{3}-\mathrm{NH}_{4}{ }^{+}$in a solid matrix (snow) is rather impossible. Kinetic exchange reactions between $\mathrm{NH}_{3}$ and $\mathrm{NH}_{4}{ }^{+}$in rainwater (PROCESS 2) is another possibility for explaining $\delta^{15} \mathrm{~N}\left(\mathrm{NH}_{4}{ }^{+}\right)$of samples from group II (Fig. 7a). The induced nitrogen isotope effect is still subject to debate as some studies report that $\mathrm{NH}_{4}{ }^{+}$ions in rainwater are slightly depleted in ${ }^{15} \mathrm{~N}$ comparing to $\mathrm{NH}_{3}$ (Freyer 1978a, b) and others that they are slightly enriched in ${ }^{15} \mathrm{~N}$ comparing to $\mathrm{NH}_{3}$ (Heaton 1987). It follows that whatever hypothesis is considered the $\delta^{15} \mathrm{~N}_{\left(\mathrm{NH}_{4}{ }^{+}\right)}$we measured is only slightly different form the initial $\delta^{15} \mathrm{~N}\left(\mathrm{NO}_{3}\right)$ during heating seasons (sample group II) in Wrocław (Fig. 7). If we then compare our data with the $\delta^{15} \mathrm{~N}\left(\mathrm{NH}_{3}\right)$ reported by Freyer (1978a, b) and Heaton (1987) fossil fuels combustion appears as the main vector of $\mathrm{NH}_{4}{ }^{+}$in rainwater, a conclusion that is supported by results from earlier studies (Górka et al. 2011 and 2012).

The last process (PROCESS 3) to be tested corresponds to exchange reactions between atmospheric $\mathrm{NH}_{4}{ }^{+}$in salts aerosols and $\mathrm{NH}_{4}{ }^{+}$in precipitation (Fig. 7c). Atmospheric $\mathrm{NH}_{4}{ }^{+}$in salts aerosols is mainly related to particles generated from suspension of soils (or soils fertilised with $\mathrm{NH}_{4}{ }^{+}$) or secondary inorganic aerosols (SIA) generated in the atmosphere. When under the form of ammonium nitrate $\left(\mathrm{NH}_{4} \mathrm{NO}_{3}\right)$ or ammonium sulfate $\left(\left(\mathrm{NH}_{4}\right)_{2} \mathrm{SO}_{4}\right), \mathrm{NH}_{3}$ is susceptible to be transported over long distances (Heeb et al. 2008). Górka et al. (2012) measured $\delta^{15} \mathrm{~N}$ in $\mathrm{PM}_{10}$ (particulate matter with an aerodynamical diameter $<10 \mu \mathrm{m}$ ) samples from the atmosphere of Wrocław from 5.0 to $13.7 \%$. It follows that dissolution of aerosols in precipitation may take place, accompanied with a nil to negligible nitrogen isotope fractionation $\left(\Delta^{15} \mathrm{~N}\right.$; Fig. 7a and c).

\section{Conclusions}

Combined chemical, isotopic and statistical analyses provided critical information about the genesis of ions in precipitation in the atmosphere of Wroclaw. A PCA analysis discriminated them into three independent factors that lead to the following conclusions:

$-\mathrm{HCO}_{3}{ }^{-}, \mathrm{NO}_{3}{ }^{-}, \mathrm{NO}_{2}{ }^{-}, \mathrm{NH}_{4}{ }^{+}$and $\mathrm{SO}_{4}{ }^{2-}$ result of emissions from direct fertilizers usage, sewage irrigation fields activity and fossil fuel combustion.

- The study of $\mathrm{K}^{+}, \mathrm{Ca}^{2+}$ and $\mathrm{Mg}^{2+}$ concentrations and PCA analysis suggest that fertilised soil, fossil fuel combustion (road traffic and industrial) and natural dust are the main sources.

- Marine aerosols, as expected, bring $\mathrm{Na}^{+}$and $\mathrm{Cl}^{-}$ions to the city. 
The implication and relative contributions of the processes controlling the overall budget of these ions vary following three distinct seasons: heating seasons I and II and vegetative season. The study of $\delta^{15} \mathrm{~N}\left(\mathrm{NH}_{4}^{+}\right)$shows that the dissolving of primary and secondary salts aerosols within the atmoshere of Wroclaw is prevailing in the $\mathrm{NH}_{4}{ }^{+}$budget. During the heating seasons (I \& II) our data suggest that the main source of $\mathrm{NH}_{3}$ in precipitation is fossil fuels combustion while during the vegetative season local fertilisers and the Osobowice sewage irrigation fields are dominating.

Acknowledgments This research was supported by grants from the University of Wrocław No. 1017/S/ING/ 10-XII/mmod (for MM), 1017/S/ING/10-IX/mg (for MG) and 1017/S/ING/10-IX/at (for AT-O).

Open Access This article is distributed under the terms of the Creative Commons Attribution 4.0 International License (http://creativecommons.org/licenses/by/4.0/), which permits unrestricted use, distribution, and reproduction in any medium, provided you give appropriate credit to the original author(s) and the source, provide a link to the Creative Commons license, and indicate if changes were made.

\section{References}

Ali, K., Momin, G., Tiwari, S., Safai, P., Chate, D., Rao, P.: Fog and precipitation chemistry at Delhi, North India. Atmos. Environ. 38, 4215-4222 (2004)

Al-Momani, I.F., Momani, K.A., Jaradat, Q.M.: Chemical composition of wet precipitation in Irbid, Jordan. J. Atmos. Chem. 35, 47-57 (2000)

Avila, A.: Time trends in the precipitation chemistry at a mountain site in northeastern Spain for the period 19831994. Atmos. Environ. 30, 1363-1373 (1996)

Ayres, G.P., Gillet, R.W., Selleck, P.W., Bentley, S.T.: Rainwater composition and acid deposition in the vicinity of the fossil fuel-fired plants in southern Australia. Water Air Soil Pollut. 85, 23132318 (1995)

Baker, K., Scheff, P.: Photochemical model performance for PM2.5 sulfate, nitrate, ammonium, and precursor species $\mathrm{SO}_{2}, \mathrm{HNO}_{3}$, and $\mathrm{NH}_{3}$ at background monitor locations in the central and eastern United States. Atmos. Environ. 41(29), 6185-6195 (2007)

Bateman, A.S., Kelly, S.D.: Fertilizer nitrogen isotope signatures. Isot. Environ. Health Stud. 43, 237 (2007)

Battye, W., Aneja, V.P., Roelle, P.A.: Evaluation and improvement of ammonia emissions inventories. Atmos. Environ. 37, 3873-3883 (2003)

Behera, S.N., Sharma, M.: Degradation of $\mathrm{SO}_{2}, \mathrm{NO}_{2}$ and $\mathrm{NH}_{3}$ leading to formation of secondary inorganic aerosols: An environmental chamber study. Atmos. Environ. 45(24), 4015-4024 (2011)

Błaś, M., Polkowska, Ż., Sobik, M., Klimaszewska, K., Nowiński, K., Namieśnik, J.: Fog water chemical composition in different geographic regions of Poland. Atmos. Res. 95, 455-469 (2010)

Boyd, S.R., Rejou-Michel, A., Javoy, M.: Noncryogenic purification of nanomole quantitles of nitrogen gas for isotopic analysis. Anal. Chem. 66, 1396-1402 (1994)

Busigny, V., Bebout, G.E.: Nitrogen in the silicate earth: speciation and isotopic behavior during mineral-fluid interactions. Elements 9(5), 353-358 (2013)

Calvo, A.I., Olmo, F.J., Lyamani, H., Alados-Arboledas, L., Castro, A., Fernández-Raga, M., Fraile, R.: Chemical composition of wet precipitation at the background EMEP station in Víznar (Granada, Spain) (2002-2006). Atmos. Res. 96(2-3), 408-420 (2010)

Cao, Y.Z., Wang, S.Y., Zhang, G., Luo, J.Y., Lu, S.Y.: Chemical characteristics of wet precipitation at an urban site of Guangzhou, South China. Atmos. Res. 94, 462-469 (2009)

Caron, F., Tessier, A.: Sulfur and oxygen isotopes of sulfate in precipitation and lakewater, Quebec, Canada. Appl. Geochem. 1(5), 601-606 (1986)

Ceron, R.M.B., Padilla, H.G., Belmont, R.D., Torres, M.C.B., García, R.M., Báez, A.P.: Rainwater chemical composition at the end of the mid-summer drought in the Caribbean shore of the Yucatan Peninsula. Atmos. Environ. 36(2), 2367-2374 (2002)

Crous, J.W., Morris, A.R., Scholes, M.C.: Growth and foliar nutrient response to recent applications of phosphorus $(\mathrm{P})$ and potassium $(\mathrm{K})$ and to residual $\mathrm{P}$ and $\mathrm{K}$ fertiliser applied to the previous rotation of Pinus patula at Usutu, Swaziland. For. Ecol. Manag. 256(4), 712-721 (2008)

Czyżyk, F., Rajmund, A.: Quantities of certain elements carried into the soil with atmospheric precipitations in Wrocław region in the years 2002-2010. Inżynieria Ekolog. 27, 5-12 (2011) (in Polish with English abstract) 
Das, R., Das, S.N., Misra, V.N.: Chemical composition of rainwater and dustfall at Bhubaneswar in the east coast of India. Atmos. Environ. 39, 5908-5916 (2005)

Denterer, F.J., Crutzen, P.J.: A three-dimensional model of the global ammonia cycle. J. Atmos. Chem. 19, 331369 (1994)

Drever, J.I.: The geochemistry of natural waters, surface and groundwater environments. Prentice Hall, Wyoming (1997)

Dubicki, A., Dubicka, M., Szymanowski, M.: Wrocław climate, Wrocław environment - informator 2002, Dolnośląska Fundacja Ekorozwoju, (ed. Smolnicki K., Szykasiuk M.), Wrocław, p.223. (http://www.eko. org.pl/wroclaw/pdf/klimat.pdf) (in Polish) (2002)

Eder, E., Bash, J., Foley, K., Pleim, J.: Incorporating principal component analysis into air quality model evaluation. Atmos. Environ. 82, 307-315 (2014)

Ernst, J.W., Massey, H.F.: The effects of several factors on volatilization of ammonia formed from urea in the soil. Soil Sci. Soc. Am. Proc. 24, 87-90 (1960)

Felix, J.D., Elliott, E.M., Gish, T.J., McConnell, L.L., Shaw, S.L.: Characterizing the isotopic composition of atmospheric ammonia emission sources using passive samplers and a combined oxidation-bacterial denitrifier approach. Rapid Commun. Mass Spectrom. 27, 2239-2246 (2013)

Frank, D.A., Evans, R.D., Tracey, B.F.: The role of ammonia volatilization in controlling the natural ${ }^{15} \mathrm{~N}$ abundance of a grazed grassland. Biogeochemistry 68, 169 (2004)

Freyer, H.D.: Preliminary ${ }^{15} \mathrm{~N}$ studies on atmospheric nitrogenous trace gases. Pageoph 116, 393-404 (1978a)

Freyer, H.D.: Seasonal trends of $\mathrm{NH}_{4}{ }^{+}$and $\mathrm{NO}_{3}{ }^{-}$nitrogen isotope composition in rain collected at Juelich, Germany. Tellus 30, 83-92 (1978b)

Galy-Lacaux, C., Modi, A.I.: Precipitation chemistry in the Sahelian Savanna of Niger, Africa. J. Atmos. Chem. 30, 319-343 (1998)

Gao, Y.: Atmospheric nitrogen deposition to Barnegat Bay, 2002. Atmos. Environ. 36, 5783-5794 (2002)

Gomółka, B.: Ćwiczenia laboratoryjne z chemii wody, vol. 3, p. 166. Oficyna Wydawnicza Politechniki Wrocławskiej, Wrocław (1998). In Polish

Górka, M., Jędrysek, M.O., Strapoć, D.: Isotopic composition of sulphates from meteoric precipitation as an indicator of pollutant origin in Wrocław (SW Poland). Isot. Environ. Health Stud. 44(02), 177-188 (2008)

Górka, M., Sauer, P.E., Lewicka-Szczebak, D., Jędrysek, M.-O.: Carbon isotope signature of dissolved inorganic carbon (DIC) in precipitation and atmospheric $\mathrm{CO}_{2}$. Environ. Pollut. 159, 294-301 (2011)

Górka, M., Zwolińska, E., Malkiewicz, M., Lewicka-Szczebak, D., Jędrysek, M.-O.: Carbon and nitrogen isotopic analysis coupled with palynological data of PM10 in Wrocław city (SW Poland) - assessment of anthropogenic impact. Isot. Environ. Health Stud. 48(02), 327-344 (2012)

Górka, M., Lewicka-Szczebak, D., Fuß, R., Jakubiak, M., Jędrysek, M.-O.: Dynamics and origin of atmospheric $\mathrm{CH}_{4}$ in a Polish metropolitan area characterized by wetlands. Appl. Geochem. 45, 72-81 (2014)

Heaton, T.H.E.: ${ }^{15} \mathrm{~N} /{ }^{14} \mathrm{~N}$ ratios of nitrate and ammonium in rain at Pretoria, South Africa. Atmos. Environ. 21, 843-852 (1987)

Heeb, N.V., Saxer, C.J., Forss, A.M., Bruhlmann, S.: Trends of $\mathrm{NO}, \mathrm{NO}_{2}$, and $\mathrm{NH}_{3}$ emissions from gasolinefueled Euro-3- to Euro-4-passenger cars. Atmos. Environ. 42, 2543 (2008)

Hegg, D.A., Radke, L.F., Hobbs, P.V.: Ammonia emissions from biomass burning. Geophys. Res. Lett. 15(4), 335-337 (1988)

Hejcman, M., Kunzová, E., Šrek, P.: Sustainability of winter wheat production over 50 years of crop rotation and N, P and K fertilizer application on illimerized luvisol in the Czech Republic. Field Crop Res. 139, 30-38 (2012)

Hoering, T.: The isotopic composition of the ammonia and the nitrate ion in rain. Geochim. Cosmochim. Acta 12, 97-102 (1957)

Högberg, P.: ${ }^{15} \mathrm{~N}$ natural abundance in soil-plant systems. Tansley Review No 95. New Phytol. 137, 179-203 (1997)

Johnson, R.J.: Multivariate Statistical Analysis in Geography. Longmans, London (1978)

Jolliffe, I.T.: Principal component analysis, 2nd edn. Springer, New York (2002)

Jóźwiak, M., Kozłowski, R.: Właściwości fizykochemiczne i chemizm opadów atmosferycznych w Górach Świętokrzyskich. Pol. Geol. Rev. 53(11), 1059-1060 (2005)

Kacorzyk, P., Kasperczyk, M., Szewczyk, W.: Nutrients load deposited with precipitations on the Earth surface in mountains areas. Water-Environ.-Rural Areas T. 12. Z. 4(40), 145-150 (in Polish with English abstract) (2012)

Kendall, C., Grim, E.: Combustion tube method for measurement of nitrogen isotope ratios using calcium oxide for total removal of carbon dioxide and water. Anal. Chem. 62, 526-529 (1990)

Kmieć, G., Zwoździak, A., Kacperczyk, K., Zwoździak, J.: Meteorological aspect of chemical composition of precipitation/deposition - long range pollution transport in a mountain region. In: Gryning, S.-V., Millan, M. M. (Eds.) Air pollution modeling and its application X, New York, pp. 635-636 (1994) 
Lee, K.S., Lee, D.S., Lim, S.S., Kwak, J.H., Jeon, B.J., Lee, S.I., Lee, S.M., Choi, W.J.: Nitrogen isotope ratios of dissolved organic nitrogen in wet precipitation in a metropolis surrounded by agricultural areas in southern Korea. Agric. Ecosyst. Environ. 159, 161-169 (2012)

Lehmann, M.F., Bernasconi, S.M., McKenzie, J.A.: A method for the extraction of ammonium from freshwaters for nitrogen isotope analysis. Anal. Chem. 73, 4717-4721 (2001)

Lim, C., Jang, J., Lee, I., Kim, G., Lee, S.-M., Kim, Y., Kim, H., Kaufman, A.J.: Sulfur isotope and chemical compositions of the wet precipitation in two major urban areas, Seoul and Busan, Korea. J. Asian Earth Sci. 79A, 415-425 (2014)

Manly, B.F.J.: Multivariate statistical methods. Capman and Hall, New York (1998)

Meteorological Bulletin: Wrocław Biskupin 2010 I-XII, Department Of Climatology and Atmosphere Protection, Institute of Geography and Regional Development, University of Wrocław, Year 3, vol. 25-36 (http://www. meteo.uni.wroc.pl/index.php?option=com_content\&view=article\&id=57\&Itemid=42) (2010)

Migliavacca, D., Teixeira, E.C., Wiegand, F., Machado, A.C.M., Sanchez, J.: Atmospheric precipitation and chemical composition of an urban site, Guaiba hydrographic basin, Brazil. Atmos. Environ. 39, 1829-1844 (2005)

Moore, H.: Isotopic measurement of atmospheric nitrogen compounds. Tellus 26(1-2), 169-174 (1974)

Moore, H.: The isotopic composition of ammonia, nitrogen dioxide and nitrate in the atmosphere. Atmos. Environ. 11, 1239-1243 (1977)

Paerl, H.W., Fogel, M.L.: Isotopic characterization of atmospheric nitrogen inputs as sources of enhanced primary production in coastal Atlantic Ocean waters. Mar. Biol. 119, 635-645 (1994)

Parungo, F., Nagamoto, C., Hoyt, S., Bravo, H.: The investigation of air quality and acid rain over the Gulf of Mexico. Atmos. Environ. 24A(1), 109-123 (1990)

Plaisance, H., Coddeville, P., Guillermo, R., Roussel, I.: Spatial variability and source identification of rural precipitation chemistry in France. Sci. Total Environ. 180, 257-270 (1996)

Plaisance, H., Galloo, J.C., Guillermo, R.: Source identification and variation in the chemical composition of precipitation at two rural sites in France. Sci Total Environ. 206(01), 79-93 (1997)

Prathibha, P., Kothai, P., Saradhi, I.V., Pandit, G.G., Puranik, V.D.: Chemical characterization of precipitation at a coastal site in Trombay, Mumbai, India. Environ. Monit. Assess. (2009). doi:10.1007/s10661-009-1090-7

Prenni, A.J., Levin, E.J.T., Benedict, K.B., Sullivan, A.P., Schurman, M.I., Gebhart, K.A., Day, D.E., Carrico, C.M., Malm, W.C., Schichtel, B.A., Collett, J.L., Kreidenweis, S.M.: Gas-phase reactive nitrogen near Grand Teton National Park: Impacts of transport, anthropogenic emissions, and biomass burning. Atmos. Environ. 89, 749-756 (2014)

Prospero, J.M., Savoie, D.L., Duce, R.A.: Particulate nitrate and non-sea-salt sulfate in the boundary layer over the Pacific Ocean. Atmos. Environ. 20(10), 2074-2075 (1986)

Puxbaum, H., Simeonov, V., Kalina, M.F.: Ten years trends (1984-1993) in the precipitation chemistry in central Austria. Atmos. Environ. 32, 193-202 (1998)

Robinson, D.: $\delta^{15} \mathrm{~N}$ as an integrator of the nitrogen cycle. Trends Ecol. Evol. 16, 153-162 (2001)

Rocha, F.R., Silva, J.A.F., Lago, C.L., Fornaro, A., Gutz, I.G.R.: Wet deposition and related atmospheric chemistry in the São Paulo Metropolis, Brazil: Part 1. Major inorganic ions in rainwater as evaluated by capillary electrophoresis with contactless conductivity detection. Atmos. Environ. 37, 105-115 (2003)

Russell, K.M., Galloway, J.N., Macko, S.A., Moody, J.L., Scudlark, J.R.: Sources of nitrogen in wet deposition to the Chesapeake Bay region. Atmos. Environ. 32, 2453-2465 (1998)

Safai, P.D., Rao, P.S.P., Momin, G.A., Ali, K., Chate, D.M., Praveen, P.S.: Chemical composition of precipitation during 1984-2002 at Pune, India. Atmos. Environ. 38, 1705-1714 (2004)

Sapek, A.: Ammonia emissions from non-agricultural sources. Pol. J. Environ. Stud. 22(1), 63-70 (2013)

Scalan, R. S.: The Isotopic composition, concentration, and chemical state of the nitrogen inigneous rocks. Unpublished $\mathrm{PhD}$ dissertation, University of Arkansas (1958)

Shearer, G.B., Kohl, D.H., Commoner, B.: The precision of determinations of the natural abundance of nitrogen15 in soils, fertilizers, and shelf chemicals. Soil Sci. 118, 308-316 (1974)

Shield, I.F., Barraclough, T.J.P., Riche, A.B..., Yates, N.E.: The yield and quality response of the energy grass Miscanthus giganteus to fertiliser applications of nitrogen, potassium and sulphur. Biomass Bioenergy 68, 185-194 (2014)

Silva, S.R., Kendall, C., Wilkison, D.H., Ziegler, A.C., Chang, C.C.Y., Avanzino, R.J.: A new method for collection of nitrate from fresh water and the analysis of nitrogen and oxygen isotope ratios. J. Hydrol. 228(1-2), 22-36 (2000)

Szynkiewicz, A., Modelska, M., Jędrysek, M.-O., Mastalerz, M.: The effect of acid rain and altitude on concentration, $\delta^{34} \mathrm{~S}$, and $\delta^{18} \mathrm{O}$ of sulfate in the water from Sudety Mountains, Poland. Chem. Geol. 249(1-2), 36-51 (2008)

Tomassi-Morawiec H., Lis J., Pasieczna A.: Geochemical atlas of Wrocław and its surroundings p..I, Polish Geological Institute, Warsaw, 4-5 (1998)

Topçu, S., Incecik, S., Atimtay, A.T.: Chemical composition of rainwater at EMEP station in Ankara, Turkey. Atmos. Res. 65, 77-92 (2002) 
Torello, W.A., Wehner, D.J.: Urease activity in a Kentucky bluegrass turf. Agron. J. 75, 654-656 (1983)

Tu, J., Wang, H.S., Zhang, Z.F., Jin, X., Li, W.Q.: Trends in chemical composition of precipitation in Najing, China, during 1992-2003. Atmos. Res. 73, 283-298 (2005)

Voivodeship Inspectorate for Environment Protection (VIfEP) in Wrocław: Report on State of Environment in Lower Silesia in 2010, http://www.wroclaw.pios.gov.pl/index.php/publikacje/raporty-o-stanie-srodowiska/ (2010)

Wang, H., Han, G.: Chemical composition of rainwater and anthropogenic influences in Chengdu, Southwest China. Atmos. Res. 99, 190-196 (2011)

Xiao, H.Y., Liu, C.Q.: Sources of nitrogen and sulfur in wet deposition at Guiyang southwest China. Atmos. Environ. 36, 5121-5130 (2002)

Xiao, H.-W., Xiao, H.-Y., Long, A., Wang, Y.-L.: Who controls the monthly variations of NH4+ nitrogen isotope composition in precipitation? Atmos. Environ. 54, 201-206 (2012)

Yoboue, V., Galy-Lacaux, C., Lacaux, J.P., Silue, S.: Rainwater chemistry and wet deposition over the wet savanna ecosystem of Lamto (C^ote d'Ivoire). J. Atmos. Chem. 52, 117-141 (2005)

Zhang, P., Dudley, N., Ure, A.M., Littlejohn, D.: Application of principal component analysis to the interpretation of rainwater compositional data. Anal. Chim. Acta 258(1), 1-10 (1992)

Zhang, Y., Kang, S., Li, C., Cong, Z., Zhang, Q.: Wet deposition of precipitation chemistry during 2005-2009 at a remote site (Nam Co Station) in central Tibetan Plateau. J. Atmos. Chem. 69, 187-200 (2012)

Zhao, Z., Tian, L., Fischer, E., Li, Z., Jiao, K.: Study of chemical composition of precipitation at an alpine site and a rural site in the Urumqi River Valley, Eastern Tien Shan, China. Atmos. Environ. 42, 8934-8942 (2008)

Zunckel, M., Saizar, C., Zarauz, J.: Rainwater composition in northeast Uruguay. Atmos. Environ. 37, 1601$1611(2003)$ 